\title{
Gender Differences in Compensation and Earnings Management: Evidence from Australian CFOs
}

\author{
Lien Duong* and John Evans
}

Curtin Business School, Curtin University

\begin{abstract}
We investigate the impact of CFO gender on CFO compensation and earnings management in Australia. In a sample of exchange-listed firms from 2006 to 2010, we find a significant gender pay gap in CFO compensation but much of this pay gap dissipates when female CFOs are matched using a propensity scoring method. Female CFOs tend to choose less risky remuneration packages with more cash and less non-cash component, with more salary and less bonus than their male peers. In addition, female CFOs are more conservative and deliver higher reporting quality compared to male CFOs. They engage substantially less in both accruals-based and real-based earnings management than their male counterparts. The difference in behavior of earnings management and in the selected compensation structures between male and female CFOs can be possibly explained by the gender-based difference in personal risk preference.
\end{abstract}

Keywords: Chief Financial Officers, Executive Compensation, Gender Pay Gap, Earnings Management, Risk Aversion, Australia.

JEL classification: G34, J33, M41

${ }^{*}$ Address for correspondence: Lien Duong (l.duong@curtin.edu.au), School of Accounting, Curtin University, Bentley campus, GPO Box U1987, Perth, Western Australia 6845 


\section{Introduction}

There has been a significant increase in female representation in corporate senior management teams over the past decades. ${ }^{1}$ According to the Australian Institute of Company Directors, the percentage of female directorship on the boards of Top 200 firms listed on the Australian Securities Exchange (ASX) has increased from $8.3 \%$ in 2009 to $20 \%$ in $2015 .^{2}$ It is generally acknowledged that executive gender plays a significant role in various corporate aspects, such as, reporting quality, compensation, firm performance, financing and acquisitions (Srinidhi et al. 2011, Lam et al. 2013, Low et al. 2015, Huang \& Kisgen 2013). Prior research has generally emphasized on the role of Chief Executive Officers (CEOs). As a result of a number of high profile corporate collapses and the enactment of legislation in the US and in Australia, the importance of Chief Financial Officers (CFOs) in firm management has been crystallized. Section 302 of the Sarbanes-Oxley Act (US) and Section 295A of the Corporations Act (Australia) require both CEOs and CFOs being personally responsible for accuracy and completeness of company financial reports. The result of these changes and the corresponding elevation of the role of CFOs enable CFOs to be treated as a unique and relatively homogeneous role within the executive ranks. $^{3}$

As responses to the greater awareness of executive gender issues and the increasingly important role of CFOs, researchers are now investigating the influence of CFO gender on compensation and earnings quality (Gayle et al. 2012, Barua et al. 2010, Ge et al. 2011, Francis et al. 2015). However, mixed results have been found and those studies have generally focused on the US market. For example, Bertrand \& Hallock (2001) do not find a gender pay gap for CFOs while Gayle et al. (2012) find a significant CFO pay difference in salary. Similar, Barua et al. (2010) and Peni \& Vahamaa (2010) find that CFO gender significantly affects discretionary accruals whereas Ge et al. (2011) do not find evidence to support this relationship. In addition, past research has mainly concentrated on accruals-based earnings management and ignored the real transactions

\footnotetext{
${ }^{1}$ Some European countries have implemented gender quotas to increase the number of female directors on the board. For example, companies in Norway are required to have at least $40 \%$ of company board members to be women since 2003. A failure to achieve this mandatory quota leads to the company being delisted in the Norwegian stock exchange. Similarly, Germany passed a law requiring $30 \%$ of board seats to be filled by women by 2016 .

${ }^{2}$ This statistics are from website of the Australian Institute of Company Directors (http://www.companydirectors.com.au/Director-Resource-Centre/Governance-and-Director-Issues/BoardDiversity/Statistics).

${ }^{3}$ There is evidence in the literature that CFOs possess superior information due to their roles in the firm's financial policy and financial reporting process (Geiger \& North 2006, Jiang et al. 2010). Wang et al. (2012) find that CFO trades are more informative about future stock returns than CEO trades. Similarly, Wang \& Wang (2014) shows that CFOs trades are predictive of new information in future earnings for firms in a poor information environment.
} 
manipulation when examining the impact of CFO gender on earnings quality. In this paper we investigate whether the CFO gender has a material impact on CFO compensation and earnings management in Australia. We contribute to the literature by examining both accruals and real earnings management. We further examine how the risk-averse characteristic of female CFOs could potentially impact on their choice of compensation structure. To our knowledge, this is the first work in Australia that investigates the gender role at the CFO level and is an important step in uncovering pay inequity and earnings management behavior in this defined executive role.

Although there are some similarities between Australia and the US, the differences between the two countries make it interesting to see if the US findings of the impact of CFO gender on compensation and earnings management also apply in Australia. Similar features of Australia and the US include a regulatory framework which requires CFOs to certify company financial reports and a low proportion but significant increase recently of female CFOs in listed corporations. Our data shows only $7.37 \%$ of Australian listed firms employ female CFOs and the similar percentage (8\%) is observed in the US market (Barua et al. 2010). The number of female CFOs has, nevertheless, increased significantly in both Australian and US corporations. In our sample, 9.52\% of Australian CFOs were women in 2010 versus $2.53 \%$ in 2006. This figure for the US market was $7.5 \%$ in 2005 versus $3 \%$ in 1994 (Huang \& Kisgen 2013).

In spite of some similarities, Australia and the US differ remarkably in some aspects. The first difference is that female and male CFOs in the US work in firms with similar total assets (Barua et al. 2010) while Australian female CFOs are employed mostly by much smaller firms. Our data shows that the median sales of firms with female CFOs is about $\$ 64$ million dollars which is approximately 9 times smaller than that in firms employing male CFOs. The board structure of Australian firms is distinguished from their US counterparts with Australian boards being smaller, having a lower proportion of executive directors and less likely being chaired by CEOs (Bugeja, da Silva Rosa, Duong \& Izan 2012). In addition, the proportion of Australian CFOs who are a member of the company board of director is roughly 5 times higher than that reported in the US market (Duong \& Evans 2015). This difference implies that Australian CFOs could be potentially involved in making more strategic decisions. Another difference between the two countries is in the structure of CFO compensation. The US CFOs are remunerated heavily towards non-cash component such as shares and options (Balsam et al. 2012) whereas Australian CFOs receive more cash component (salary and bonus) in their compensation package (Duong \& Evans 2015). The final aspect that distinguish Australia and the US is that the regulation 
on audit committees, which play an important role in constraining earnings management, is less prescriptive in Australia than that in the US (Wilson 2011). While the audit committees of all listed US firms are legislated to have solely independent directors, this requirement for Australian listed firms is to follow the best practice guidelines issued by the ASX.

Our evidence is based on the original sample of 556 firm-year observations of exchange-listed firms in Australia from 2006 to 2010. We find that female CFOs mainly work for small and medium enterprises (SMEs) and are concentrated in consumer stables and financial industries. There are no female CFOs in male-dominated industries, such as, information technologies, telecommunication and utilities. The majority of firms employ male CFOs with less than $10 \%$ of firms employing female CFOs. Female CFOs choose less risky remuneration packages by receiving significantly more in cash and less in non-cash components than male CFOs. They also have higher proportion of salary and lower proportion in bonus to total compensation than their male CFOs. Female CFOs have similar qualifications compared to their male peers and the performance of companies is not significantly impacted by the CFO gender. Women CFOs tend to own more company shares, have shorter tenure and be less likely to have a seat on the company board of directors compared with their male counterparts. In addition, companies with female CFOs are smaller in size, have lower leverage and higher percentage of female directors on the board.

In contrast to the US studies (Bertrand \& Hallock 2001, Gayle et al. 2012), it is found that there is a significant gender pay gap in Australian CFO compensation in our original sample. The average total compensation of female CFOs is less than half of that paid to their male counterparts. Furthermore, this pay gap does not decrease when there are female directors on the company board or on the compensation committee. However, the CFO gender pay gap dissipates when we replicate the original analysis with a matched sample using a propensity score matching method. It suggests that the CFO pay disparity could be the size effect as it is generally recognized that larger firms primarily offer higher remuneration packages to their executives. Despite having lower pay, female CFOs deliver higher reporting quality compared to their counterparts. It is found that female CFOs are more conservative in both accruals and real earnings management policies. Companies with female CFOs have significant lower earnings management than companies with male CFOs, and this result is robust in the propensity score setting. The gender-based difference in risk attitudes could possibly explain the different behavior of CFOs towards earnings management and the choice of remuneration packages. 
The remainder of the paper is organized as follows. Section 2 provides a brief overview of prior literature. Section 3 describes the research method, sample and data collection. In section 4 the empirical results, robustness tests and discussion of the findings are presented. The paper is concluded in Section 5 .

\section{Literature review}

\subsection{CFO gender and compensation}

During the last two decades, there have been significant positive changes in society's attitude to discrimination and equality and yet there has been little change in the gender pay gap over that period. As reported by the National Centre for Social and Economic Modeling in 2010, the gender pay gap, defined by the OECD as the difference between male and female earnings expressed as a percentage of male earnings, has remained in the narrow 15\%-17\% range since 1990. It is documented by Australian Bureau of Statistics (ABS) that the average full-time weekly earnings of women in Australia in 2012 was $18 \%$ less than that of men. ${ }^{5}$ The gender pay gap typically widens as women climb the corporate ladder. ABS data in 2012 also showed that the average weekly total cash earnings of female chief executives and managing directors was $25 \%$ less than their male counterparts. There has been ongoing discussion and an abundance of papers and reports on the question of why there is a gender pay gap. The Government of the Australian state of Queensland, in a fact sheet ${ }^{6}$ from the Department of Justice and Attorney General, listed a number of factors contributing to the gender pay gap. In particular, women are likely to be paid less because of "poor recognition of qualifications, absence of appropriate classification structures, absence of previous and detailed assessment of their work and working in industries that are female dominated" (p.2 of the fact sheet). If we critically review the cited reasons then no such gender pay gap should exist in executive roles such as CEOs and CFOs which historically have been male dominated, have a significant accountability and assessment component, and for public companies the incumbents' qualifications are on the public record.

It is however widely documented in the literature that there is a gender earnings gap at senior

\footnotetext{
${ }^{4}$ The report is from the website of the National Centre for Social and Economic Modeling (http://www.natsem.canberra.edu.au/publications/); "The impact of a sustained gender wage gap on the Australian economy" by R. Cassells, Y. Vidyattama and R. Miranti and J. McNamara, March 2010.

${ }^{5}$ Data is from the ABS website (http://www.abs.gov.au) under Category 6306.0 Employee Earnings and Hours, Australia, 2012.

${ }^{6}$ The fact sheet, titled "Why is there a gender pay gap" in September 2010, is from the website of the Department of Justice and Attorney General, Queensland (http://www.justice.qld.gov.au).
} 
management levels (e.g. Bertrand \& Hallock 2001, Kulich et al. 2011, Gayle et al. 2012, Lam et al. 2013). Women in managerial positions typically face a "glass ceiling", namely, an invisible barrier that prevents them climbing the corporate ladder (Daily et al. 1999). The obstacles that women encounter can become more prominent as they progress further in their careers (Powell 1999). As a result, there is only a very small proportion of top-level executive positions occupied by women. For example, women only account for $1.97 \%$ of CEOs in the US over the period 1998-2010 (Bugeja, Matolcsy \& Spiropoulos 2012) and 4.4\% of Chinese CEOs during the years between 2000 and 2008 (Lam et al. 2013). When taking a sample of CEOs and CFOs of listed firms in the US, Huang \& Kisgen (2013) find the proportion of female executives is $6.6 \%$ for the years 1993-2005.

The majority of work on director gender pay has looked at all executives as one group and generally supports the proposition that there is gender bias in executive compensation. Bertrand \& Hallock (2001), using a data set of the five highest-paid executives in each US firm for the years 1992-1997, show that there is a gender difference in executive pay and female executives earn significantly less than their male counterparts. Munoz-Bullon (2010) finds that male executives in the US are compensated at significantly higher levels than female executives for the years 1992 to 2006. Similarly, Shin (2012) finds a gender gap in US executive compensation over the period 1998-2005 and this gap is smaller when there is a representation of women on the board or remuneration committee. Vieito \& Khan (2012) show that executive pay gap persists for S\&P 1500 listed firms during the period from 1992 to 2004. Gayle et al. (2012) also document a significant gender pay gap of US executives for the period 1991 to 2006 . In their sample, male executives earn on average $\$ 80,000$ more than female executives in cash-based salary and $\$ 540,000$ more in total compensation. Similar to the US studies, Kulich et al. (2011) provide evidence of gender pay gap in UK corporate boardrooms during the period 1998 to 2004. Their results indicate that bonuses paid to male executives are larger than that paid to female executives. In addition, bonuses for male CEOs are more closely linked to performance while women CEOs are neither rewarded nor punished for performance.

There are numerous studies in the literature that examine the impact of gender on compensation which focus exclusively on the CEO group. The results on the association between gender and CEO compensation are mixed. Based only on univariate analyses, Jordan et al. (2007) document that female CEOs of firms in the Fortune 100 do not earn significantly less than their male peers. Bugeja, Matolcsy \& Spiropoulos (2012), investigating CEO compensation of US 
listed firm between 1998 and 2010, show that the remuneration of female CEOs is equivalent to their male counterparts. Their results are robust for both the original sample and the matched sub-sample using the propensity score matching method which identifies a control firm for each firm employing a female CEO. However, Lam et al. (2013), in a study of Chinese-listed enterprises, find that female CEOs receive significantly less compensation than male CEOs and find no evidence to explain this differential when comparing firm performance. As mentioned earlier, Bertrand \& Hallock (2001) and Gayle et al. (2012) both find a significant gender pay gap when pooling all executives in one group. However, when they control for the executive rank, their results on CEO gender pay gap is different. Bertrand \& Hallock (2001) find the gender pay gap is still persistent in the CEO group while Gayle et al. (2012) find there is no pay difference in the CEO rank.

As previously discussed, the legislative elevation of CFOs to the same level of financial oversight responsibility as CEOs has emphasized the important role of CFOs beyond that of other company executives. It indicates that CFOs should be treated as a homogeneous group within the executive ranks. There are a number of studies that have been undertaken to examine the gender pay gap in executive compensation but little work to date has specifically included the role of CFOs in this discussion. The exception is found in the US studies of Bertrand \& Hallock (2001) and Gayle et al. (2012) who separate the CFO group from other executives and examine the gender pay gap for different executive ranks. Bertrand \& Hallock (2001) do not find the difference in pay between male and female CFOs whereas Gayle et al. (2012) find a significant CFO pay difference in salary but not total compensation. However, the CFO group in the study of Gayle et al. (2012) is "contaminated" as it also contains other company executives such as Vice President and Chief Operating Officer. Moreover, their analysis of the CFO group is limited to univariate evidence. In this paper we aim at filling this gap by investigating the impact of gender on CFO compensation in Australia. We investigate further to see if the compensation structure of CFOs is different with their gender. Our first research question is to examine whether there is a significant variance between Australian male and female CFOs in terms of compensation level and compensation structure.

\subsection{CFO gender and earnings management}

Although the gender pay gap exists at the senior management team, there is evidence in the literature that female directors can positively affect financial reporting quality through engaging 
less in earnings management. Carter et al. (2003) show that female directors are more likely to exercise greater independence than male counterparts. Adams \& Ferreira (2009) find that gender-diverse boards exhibit more diligence and demand greater accountability for managers' performance. These studies suggest that female directors could improve board oversight and monitoring and thereby improve earnings quality. Labelle et al. (2010) find that gender diversity in senior management team is positively associated with earnings quality. Similarly, Srinidhi et al. (2011) document that firms with female directors on the board have higher quality of reported earnings than firms without gender-diverse boards.

The literature on gender-based psychological differences suggests that women and men exhibit distinct values and interests, and these characteristic differences may also influence their behavior in work life (Byrnes et al. 1999, Betz et al. 1989). Women are generally more cautious and risk-averse than men in making financial decisions (Riley \& Chow 1992, Sunden \& Surette 1998). Levi et al. (2014) provide evidence that acquiring firms with female CEOs pay significantly lower takeover premiums than acquiring firms with male CEOs. Huang \& Kisgen (2013) find that female executives (CEOs and CFOs) are more cautious in evaluating acquisitions and in issuing debt. As compared to bidding firms with male executives, firms with female executives achieve higher announcement returns even though they make a significantly less number of acquisitions. Female executives are also less likely to issue debt and more likely to reduce the leverage ratio than their male counterparts (Huang \& Kisgen 2013). Francis et al. (2015) further document that female CFOs are more conservative in their financial reporting practices. Their study strongly supports the assertion that female CFOs are more risk-averse than male CFOs.

In addition to risk aversion, women tend to be less acrimonious and are more likely to comply with rules and regulations whereas men are interested in economic benefits and more likely to break rules to achieve success (Baldry 1987, Betz et al. 1989). Lenney (1977) finds that gender differences are particularly prevalent in ambiguous situations and in areas that require executive judgement such as earnings management. Peni \& Vahamaa (2010) and Barua et al. (2010) analyze the association between CFO gender and abnormal accruals for US companies and find that firms with female CFOs have higher quality of accruals than firms with male CFOs. The result is likely due to the fact that female executives are more cautious, risk-averse and likely to act more decisively than their male counterparts in improving earnings quality (Barua et al. 2010, Srinidhi et al. 2011). However, Ge et al. (2011) do not find evidence that CFO gender 
significantly affects discretionary accruals among US firms.

There are two main types of earnings management practices: accruals management (AM) and real transactions management (RTM). AM depicts choices managers make to attain earnings objectives through the selection of generally accepted accounting methods and discretionary estimates of accruals. In contrast to AM, RTM describes activities where managers try to meet earnings objectives by changing the timing or structuring of an operating, investing or financing decision (Badertscher 2011). It is shown in the literature that firms may switch between the AM and RTM methods (Graham et al. 2005, Roychowdhury 2006, Cohen et al. 2008, Badertscher 2011). Badertscher (2011) argues that accruals management would be a popular choice for managers because it has no first-order effect on cash flows and is therefore less likely to destroy long-term value. In contrast, real transactions manipulation harms future cash flows, has adverse impact on optimal business operations and potentially damages long-term firm value (Roychowdhury 2006, Cohen et al. 2008). The literature about the impact of female CFOs on earnings management concentrates mainly on accruals-based management (Peni \& Vahamaa 2010, Barua et al. 2010, Ge et al. 2011). To the best of our knowledge, there is no current study that examines the influence of female CFOs on the real-based earnings management choice.

Although CFOs are primarily responsible for reporting company financial results, the majority of Australian research focuses on examining the role of CEOs on earnings quality (Wilson 2011). Jiang et al. (2010) find CFOs have more influence on earnings management than CEOs, suggesting that the impact of CFOs on earnings quality should be more thoroughly investigated. As discussed previously, the importance of CFOs has significantly increased with the demand for reliable and accurate financial information. Legislation has elevated the role of CFOs and made both CEOs and CFOs responsible for the accuracy and completeness of company financial reports. There is limited evidence about the effect of CFO gender on earnings management in Australia and the results in the US market are mixed. Our second research question is to examine whether CFO gender influences earnings quality in the Australian market. It is hypothesized that female CFOs would engage in less earnings management practices since they tend to be more conservative compared to their male peers. 


\section{Data and methodology}

\subsection{Research method - CFO compensation level and structure}

The following model is estimated to investigate our first research question, namely, whether $\mathrm{CFO}$ gender has an impact on the level and the structure of $\mathrm{CFO}$ compensation:

$$
\begin{aligned}
\text { CFOCompensation }=\alpha & +\beta(\text { FemaleCFOs })+\delta_{k}(\text { CFOCharacteristics })+ \\
& +\theta_{m}(\text { GovernanceCharacteristics })+\lambda_{n}(\text { FinancialCharacteristics }) \\
& +[\text { YearDummies }]+[\text { IndustryDummies }]+\epsilon
\end{aligned}
$$

The dependent variable in equation (1) is the compensation paid to CFOs during the year or the structure of their compensation. For the level of CFO compensation, we examine four measures: annual bonus, annual salary, total annual non-cash compensation (the sum of restricted stock rewards and stock option awards granted to CFOs), and total annual compensation (the sum of total cash and non-cash compensation). For the structure of CFO compensation, we calculate the proportion of salary, bonus, cash and non-cash compensation to their total compensation

The variable of interest, Female CFOs, is a binary variable equal to 1 if the company CFO is female. If there is a gender pay gap at CFO level, it is expected that the coefficient of Female CFOs variable is significantly negative. The remaining independent variables in model (1) are from the prior literature in executive compensation and provide controls for $\mathrm{CFO}$, governance and company financial characteristics. Our first control for CFO characteristics is a binary variable equal to 1 if the CFO has an MBA degree (MBA Qualification). The second measure of CFO characteristics is the number of years in service of the current CFO (CFO Tenure). We also include the percentage of company shares owned by the CFO (CFO Ownership) as our next control variable. The last control is an indicator variable equal to 1 if the CFO is a member of the company board of directors (CFO Board). It is reasonable to expect that firms will compensate more for CFOs with higher qualification. Banghoj et al. (2010) shows that there is a significantly positive relationship between compensation paid to executives and their level of education in Danish private firms. CFOs that have a longer tenure with the firm, or have greater equity ownership, or have a seat on the board of directors are expected to exert greater influence over the board on setting their remuneration (Bedard et al. 2014, Duong \& Evans 2015).

For corporate governance, we control for the presence of female directors on the board or on the remuneration committee. Shin (2012), based on the social identity theory of Hogg \& Terry (2000), suggests that female directors would evaluate female executives more favorably than 
they would evaluate male executives. He finds that the gender pay gap in executive compensation is smaller when there is a greater proportion of female directors on the board or on the compensation committee. Based on the findings of Shin (2012), we include the percentage of female directors on the board or on the remuneration committee ${ }^{7}$ in the regression (1). In addition, the interaction variable between the presence of female directors on the board (or the compensation committee) and the Female CFOs dummy variable is also included in the model (1). We also control for differing structures of the company board of directors. The number of directors on the board (Board Size) and the percentage of executive directors on the board (Insider Ratio) are used as measures of board governance characteristics. As evidenced in Rosenstein \& Wyatt (1990) and Yermack (1996), smaller boards and boards with higher proportions of outside directors are more effective and may act to constrain executive compensation.

Consistent with prior work on executive compensation (e.g. Murphy 1985, Smith \& Watts 1992, Bedard et al. 2014, Ferreira et al. 2013), we include sales, firm leverage, growth opportunity and firm performance as financial control variables. We use Sales as measured by the natural logarithm of company sales in the previous year to control for size. Firm leverage is calculated as total debt divided by the market value of equity in the previous year. The firm growth opportunity is captured by the market-to-book equity ratio $(M / B$ ratio), and is winsorized at the $1^{\text {st }}$ and $99^{t h}$ percentiles in order to control for outliers in the data. Finally, firm performance is controlled for by using both accounting and market performance measures. The market measure chosen is the company's annual common stock return (Stock Returns) and the selected accounting measure is return on assets $(R O A)$. The evidence presented in the literature generally concludes that executive compensation is higher for companies with larger size, greater investment/growth opportunities, and better firm performance.

\subsection{Research method - Earnings management}

To investigate the second research question on the impact of CFO gender on earnings management, the following model is firstly estimated:

$$
\begin{aligned}
\text { EarningsManagement }= & +\beta(\text { FemaleCFOs })+\delta_{k}(\text { CFOCharacteristics })_{k} \\
& +\theta_{m}(\text { GovernanceCharacteristics })_{m}+\lambda_{n}(\text { FinancialCharacteristics })_{n} \\
& +[\text { YearDummies }]+[\text { IndustryDummies }]+\epsilon
\end{aligned}
$$

The dependent variable of model (2) can be measures of accruals management $(A M)$ or real

\footnotetext{
${ }^{7}$ These two variables are included alternatively in the model (1) due to their high degree of correlation.
} 
transactions management $(R T M)$. To proxy for accruals management, we estimate the accrual estimation errors using the model of Dechow \& Dichev (2002). The $A M$ measure is computed as the absolute value of residuals from equation (3) below:

$$
\Delta W C_{t}=\beta_{0}+\beta_{1}(C F)_{t}+\beta_{2}(C F)_{t-1}+\beta_{3}(C F)_{t+1}+\epsilon
$$

In equation (3), $\Delta W C_{t}$ represents the changes in working capital from year $t$-1 and year $t$ and is calculated as the difference between the changes in current assets and the changes in current liabilities. $\Delta W C_{t}=\left(\Delta C A_{t}-\Delta \operatorname{Cash}_{t}\right)-\left(\Delta C L_{t}-\Delta S T D e b t_{t}\right)$. Cash and short-term debt are excluded because they do not represent operating accruals. All variables in equation (3) are scaled by average total assets. Dechow \& Dichev (2002) define accruals quality in terms of the extent to which current accruals is associated with current, previous and subsequent year cash flows. Therefore, the residuals from the equation (3) measure (inverse) discretionary accruals quality. A high value of the accrual estimation errors implies poor accruals quality and firms are likely to engage in accruals management.

To proxy for $R T M$, we follow the method of Roychowdhury (2006) who investigates the alteration in real activities by examining the manipulation of cash flows from operations (CF), discretionary expenditures ${ }^{8}$ and production costs. ${ }^{9}$ As data on cost of goods sold and discretionary expenses are not available on DatAnalysis database for Australian companies, ${ }^{10}$ we adopt the methodology of Duong \& Evans (2015) by investigating the manipulation of real activities on $\mathrm{CF}$ and capital expenditures (CAPEX) since firms can reduce reported expenses and increase earnings by reporting higher amount of capital expenditures. ${ }^{11}$ Following Roychowdhury (2006) and Duong \& Evans (2015), the normal level of CF and CAPEX are estimated for each industry and year using the following equations:

$$
\begin{gathered}
C F_{t} / T A_{t-1}=\alpha_{0}+\alpha_{1}\left(1 / T A_{t-1}\right)+\alpha_{2}\left(\text { Sales }_{t} / T A_{t-1}\right)+\alpha_{3}\left(\Delta \text { Sales }_{t} / T A_{t-1}\right)+\epsilon_{t} \\
\text { CAPE } X_{t} / T A_{t-1}=\alpha_{0}+\alpha_{1}\left(1 / T A_{t-1}\right)+\alpha_{2}\left(\text { Sales }_{t-1} / T A_{t-1}\right)+\epsilon_{t}
\end{gathered}
$$

\footnotetext{
${ }^{8}$ Discretionary expenditures are calculated as the sum of R\&D, advertising, general and administrative (SG\&A) expenses.

${ }^{9}$ Production costs are computed as the sum of cost of goods sold (COGS) and change in inventory.

${ }^{10}$ DatAnalysis do not report figures on COGS, R\&D expenses and advertising expenses separately for Australian companies.

${ }^{11}$ Under Australian income tax law (Section 40-880 of Income Tax Assessment Act 1997), companies which incur business capital expenditure for a project at its preliminary stage can either (1) capitalize the incurred expenditure and deduct it over a period of 5 income years, or (2) deduct the capital expenditure in the income year in which it is incurred. Therefore, capital expenditures can potentially affect the current period expenses and earnings.
} 
where $T A_{t-1}$ is total assets at time $t-1, \Delta$ Sales $_{t}=$ Sales $_{t}-$ Sales $_{t-1}$

The residuals from the regressions (4) and (5) measure the abnormal CF and abnormal CAPEX, respectively. Consistent with recent research by Zang (2012) and Duong \& Evans (2015), the abnormal $\mathrm{CF}$ and abnormal CAPEX are aggregated into one measure, RTM, in order to capture the total effect of altering real activities. The higher absolute value of $R T M$ suggests that firms have a greater use of real transactions to manage earnings.

Our independent variables in model (2) are similar to those used in model (1). It is expected that Female CFOs variable is negatively associated with all inverse measures of earnings quality as firms with female CFOs would be more likely to have higher earnings quality (Barua et al. 2010). These earnings quality models control for some of CFO characteristics (CFO Board, CFO Ownership and CFO Tenure) that proxy for CFO power. Powerful CFOs will have greater ability to manage earnings and therefore we expect a positive relationship (Srinidhi et al. 2011, Duong \& Evans 2015). We also control for corporate governance factors such as the presence of female directors on the board or on the remuneration committee (Female Dir. Board or Female Dir. Remu.), the size of audit committee (AC Size) and the proportion of audit committee members that have accounting financial expertise $(P A F E)$. We expect negative signs on these corporate governance factors (Srinidhi et al. 2011, Dhaliwal et al. 2010). In addition, there are a number of company financial characteristics included in model (2) as control variables. We expect a negative coefficient for firm size as management in larger firms face more pressure to report predictable earnings (Kothari et al. 2005). Firm leverage and M/B ratio are predicted to have positive signs (Dechow \& Dichev 2002, Menon \& Williams 2004). To control for volatility, we include the proportion of reporting loss over the last 6 years $(\%$ Loss), standard deviation of sales $(\operatorname{Std} \operatorname{dev}($ Sales/TA)) and cash flow from operations $(\operatorname{Std} \operatorname{dev}(C F / T A))$. We predict a positive association between volatility and earnigs quality (Dechow \& Dichev 2002, Bedard et al. 2014).

In models (1) and (2), we also control for industry and time fixed effects due to the differences in $\mathrm{CFO}$ compensation and earnings management across industries ${ }^{12}$ and over time. Following Petersen (2009), we estimate the standard errors of the coefficients using clustered standard errors as this method better accounts for the dependence in a panel data set (Rogers 1993).

\footnotetext{
${ }^{12}$ Firms are sorted according to their 2-digit Global Industry Classification System (GICS) codes.
} 


\subsection{Sample and data}

Our data is extracted from the Top 500 firms by market capitalization listed on the ASX between 2006 and 2010. Data on CFO compensation, CFO characteristics and corporate governance for each company are taken from the $S \& P$ Capital $I Q$ database. Where the information in the $S E P$ Capital IQ database is not available, we extract the data from the firm's annual report. Company financial data are obtained from Aspect FinAnalysis database. We exclude from the sample all companies with a change in CFO in any year and any observations with missing data. Our final sample consists of 556 firm-year observations. Table 1 provides a summary of definitions of the variables used in the study together with the data sources.

[Insert Table 1]

Table 2 shows the frequency of firms with female CFOs classified by industry. It is clear that the majority of firms employ male CFOs. In an era where the majority of graduates from Australian business schools is female, ${ }^{13}$ the number of female CFOs remain low with only $7.37 \%$ of our sample companies employing female CFOs. Female CFOs are concentrated in consumer staples and financial industries and there is no representation of female CFOs in male-dominated industries such as information technologies, telecommunications and utilities.

[Insert Table 2]

\section{$4 \quad$ Empirical results}

\subsection{Univariate analysis}

Table 3 presents descriptive data on the total pooled sample as well as the two sub-samples partitioned by CFO gender. Panel A of Table 3 shows all variables used in the analysis of CFO compensation, while Panel B presents additional variables needed for examining earnings management. It is clear from Panel A of Table 3 that female CFOs are paid significantly less than their male counterparts in all types of compensation for the years 2006-2010. The average amount of salary paid to female CFOs is $34 \%$ less than what male CFOs earn. The average total remuneration of female CFOs is $\$ 566,428$ which is less than a half of the average of $\$ 1.2$ million in remuneration for male CFOs. For the bonus component, the difference between pay of men and women is far greater: female CFOs on average receive $\$ 75,908$ which equates to only a quarter of the bonus paid to their male peers $(\$ 300,575)$. The story of male CFOs earning

\footnotetext{
${ }^{13}$ The average percentage of Australian female graduates in the field of management and commerce course between 2010 and 2012 is 52\%. Data is obtained from Department of Education (Australian Government), Higher Education Statistics Data Cube (uCube).
} 
more than female CFOs is also reported in a December 2012 study published by the Australian Financial Review newspaper. ${ }^{14}$ In this survey, it is shown that the average remuneration of the 10 highest paid male CFOs is $\$ 4.39$ million which is more than three times of the average $\$ 1.37$ million paid for female CFOs.

[Insert Table 3]

In terms of compensation structure, female CFOs get paid significantly more in cash and less in non-cash components compared to male CFOs. ${ }^{15}$ We find that the mean and median differences of the proportion of cash-based and equity-based compensation between male and female CFOs are both statistically significant. While female CFOs receive $87 \%$ of their total compensation in cash and the remaining $13 \%$ in non-cash component, the figures for male CFOs are $83 \%$ and $16 \%$, respectively. Within the cash compensation, female CFOs have a significantly larger proportion of salary and a smaller percentage of bonuses than that of their male counterparts. The salary paid to female CFOs accounts for $65 \%$ of their total compensation and their bonus component contributes a further $12 \%$. For male CFOs, the percentage of salary to their total compensation is only $57 \%$ but the proportion of their bonus component makes up $18 \%$. The difference in compensation structure suggests that female CFOs may be less risk-taking than male CFOs. This assertion is consistent with previous findings in the literature that women are relatively more risk averse than men (Sunden \& Surette 1998, Agnew et al. 2003).

Panel B of Table 3 displays descriptive statistics of all three measures of earnings management ( $A M$ for accruals management and RTM for real transactions management) when the sample is separated by CFO gender. The mean and median of both measures are lower for firms with female CFOs compared with firms having male CFOs. Univariate tests of differences show that the median of $A M$ is significantly lower while the average figure of $R T M$ is significantly smaller for firms with female CFOs. Panel B provides preliminarily evidence that earnings quality is higher for firms with female CFOs.

Table 3 also describes the financial and governance characteristics of firms divided by the CFO gender. There is no significant difference in $\mathrm{M} / \mathrm{B}$ ratio, ROA, stock returns, volatility in sales and cash flow between firms with male or female CFOs. However, the proportion of loss years

\footnotetext{
14 "Top CFOs' pay rises 10pc" by S. Durummond and E. Tadros, Australian Financial Review newspaper, 10 December 2012.

${ }^{15}$ Overall, Australian CFOs receive an average annual total compensation of $\$ 1.16$ million during the period 2006-2010 with more than $84 \%$ of their total compensation in cash and approximately $15 \%$ in non-cash component. This is similar to the compensation structure paid to Australian CEOs whose remuneration is weighted heavily towards the cash component (Chalmers et al. 2006, Bugeja, da Silva Rosa, Duong \& Izan 2012).
} 
over the preceding 6-year period is significantly higher for the sample with female CEOs. In addition, firms with female CFOs are significantly smaller in size and have lower leverage. Our finding of lower leverage in firms with female CFOs is consistent with the work of Huang \& Kisgen (2013) who found that male executives issue debt more often than female executives. Their finding may suggest that male CFOs exhibit relative overconfidence in significant corporate decision making compared with women CFOs.

In total, $21 \%$ of CFOs have an MBA degree and there is no significant difference across the gender of CFOs. ${ }^{16}$ Female CFOs own significantly more company shares, have shorter tenure and are less likely to have a seat on the board of directors when compared with male CFOs. Firms with female CFOs have a significant higher proportion of female directors on the board than firms with male CFOs. However, the percentage of female directors on the remuneration committee is not different by CFO gender. Consistent with the firm size effect, firms with a female CFO have a significantly smaller board size and audit committee size and more inside directors on the board. The proportion of audit committee members that have accounting financial expertise is higher for firm with female CFOs, but this difference is not statistically significant.

\subsection{Multivariate analysis}

The previous section shows the univariate analysis of the difference of CFO compensation and earnings management in firms with female and male CFOs. In this section, the multivariate models (1) and (2) are estimated to control for factors other than the gender effect that may influence CFO compensation and earnings quality respectively.

\subsubsection{CFO compensation}

As a number of firms do not pay bonuses or offer an equity component, that is, there are zero values in bonus and total non-cash compensation, we separate CFO compensation into two subsamples for the regression analysis. The first sub-group is compensation figures using dollar value (full sample) and the second sub-group is compensation figures measured in logarithmic

\footnotetext{
${ }^{16}$ In the pooled sample, $73 \%$ of CFOs have either CA or CPA qualification and no gender difference is observed. We do not add the CA/CPA qualification variable in our model (1) and (2) as it is an insignificant variable in the regression analysis. The insignificant result of CPA variable is also observed in a study of Loyeung \& Matolcsy (2015) when they examine Australian CFO compensation in the transition year to International Financial Reporting Standards (IFRS).
} 
scale (sample without zero-value compensation).

Table 4 presents the regression results when compensation data is expressed in dollar value. In Panel A of Table 4, we show the tobit regression results of bonus and total non-cash compensation since this group contains a number of zero-value observations. The ordinary least squares (OLS) results of salary and total compensation are presented in Panel B. As can be seen from the two panels of Table 4, the coefficient on the experimental variable, Female CFOs, is significantly negative in all models. This indicates that there is a significant gender pay gap and male CFOs receive higher compensation than their female counterparts. This finding is consistent with the univariate evidence reported in Table 3 and with previous studies on executive gender pay gap (Kulich et al. 2011, Shin 2012, Lam et al. 2013).

[Insert Table 4]

The coefficients for the proportion of female directors on the board (\% Female Board) and on the remuneration committee (\% Female Remu.) variables are both significantly positive. It suggests that CFOs, in general, receive more compensation when there is a greater representation of women on the board or on the remuneration committee. However, the gender pay gap in CFO compensation is not significantly reduced when there is a presence of female directors on the board or on the compensation committee. The interaction term between the female indicator variable, $C F O$ Female, and the presence of women on the board (or on the compensation committee) is statistically insignificant. This finding is consistent with the work of Lam et al. (2013) in their investigation of CEO compensation in Chinese companies. They find the participation of women on the company board of directors does not increase female CEO remuneration.

The results for control variables are generally consistent with previous studies in the literature. CFOs with an MBA degree receive significantly more in bonus and total non-cash compensation, suggesting that CFOs are paid for their talent and efforts. CFOs who are board members earn more in salary, indicating that CFOs use their power to extract greater pay and this is consistent with the finding in Duong \& Evans (2015). As expected, larger firms and those with the greater number of directors on the board pay CFOs more in all types of compensation. Firms with higher growth potential (as measured by the market-to-book ratio) reward their CFOs more in the non-cash component. This finding may suggest that high growth opportunity firms have less liquidity relative to lower growth opportunity firms and are more inclined to use shares to compensate their CFOs. The Stock Returns variable is found to be significantly positive in bonus 
and non-cash compensation. Our finding of a positive association between CFO compensation and stock performance measure is also evident in previous studies (Balsam et al. 2012, Hoitash et al. 2012, Bedard et al. 2014, Duong \& Evans 2015).

The analysis presented in Table 4 contains a number of variables that are right skewed (all CFO compensation and CFO Ownership variables (see statistics in Table 3). To mitigate the problem, we conduct an additional test and transform the variables using logarithmic scales. Table 5 presents the results of the analysis of the transformed variables. The results in Table 5 are similar to those in Table 4 with a significantly negative association between the CFO Female variable and all types of CFO compensation. The gender disparity in CFO compensation is persistent when using transformed variables. Women who rise through the "glass ceiling" to the level of CFO are still remunerated lower than their male counterparts. In addition, this pay gap does not narrow when there is a higher percentage of female directors on the board or on the compensation committee.

[Insert Table 5]

Our univariate evidence shows that there is no difference in corporate performance between firms employing female and male CFOs (see Table 3). However, it is found in the UK that the pay-forperformance sensitivity is higher for male executives than female executives (Kulich et al. 2011). To examine this relationship for CFOs at the multivariate level, we then introduce into the model (1) two interaction variables between Female CFO variable and both the accounting and stock performance measures (ROA and Stock Returns). These interaction variables are found to be insignificant and the remaining results are unchanged from those previously reported in Table 4 and 5 for the original sample.

In Table 4 and Table 5, the coefficient of the CFO Board variable is significantly positive for salary compensation. It implies that CFOs who sit on the board are rewarded higher salary compensation due to having more responsibilities (Duong \& Evans 2015). To exclude the additional impact of CFO board membership on their compensation, we separate the original sample into two sub-samples: the first sub-sample contains 249 observations in which the CFO has a seat on the board and the second sub-sample consists of 307 observations in which the CFO is not a board insider. The proportion of female CFOs is $5.22 \%$ in the first sub-sample and $9.12 \%$ in the second sub-sample. We then replicate Table 4 and Table 5 for the two sub-samples separately. The untabulated results show that the Female CFOs variable is significantly negative 
in all types of compensation and it is consistently observed for both sub-samples. For example, female CFOs receive approximately $\$ 1$ million (or $\$ 380,000$ ) less in total compensation than that of male CFOs in the first (or second) sub-sample. This indicates that our finding of the CFO gender pay gap is unchanged when controlling for the effect of CFO board membership on compensation.

\subsubsection{CFO compensation structure}

Table 6 displays the multivariate regression results for the structure of CFO compensation. The tobit regression results of the proportion of bonus and the proportion of non-cash to total compensation are presented in Panel A of Table 6 as they have zero-value observations. The OLS results of the proportion of salary and the proportion of cash component to total compensation are shown in Panel B of Table 6. It can be seen from Table 6, the coefficient of Female CFOs variable is significantly negative under the Prop. Bonus and Prop. Non-cash categories while it is significantly positive under the Prop. Salary and Prop. Cash components. Female CFOs receive lower proportion in bonus and non-cash compensation, but have higher proportion in salary and cash compensation. This is consistent with the univariate result presented in Table 3 that female CFOs choose to have less-risky remuneration packages. It may be due to the fact that women are generally more risk averse than men (Sunden \& Surette 1998, Agnew et al. 2003).

[Insert Table 6]

Similar to the case of CFO compensation that is expressed in natural logarithm (Table 5), the percentage of female directors on the board ( $\%$ Female Board) and on the remuneration committee (\% Female Remu.) variables are all significantly positive for the proportion of CFO non-cash compensation. It indicates that CFOs receive higher proportion in their non-cash component when there is women representation on the board or on the remuneration committee. We also find that CFOs who stay longer in their position are paid significantly higher proportion in cash. Similarly, CFOs of firms with bigger size of the board or with more executive directors on the board receive higher percentage of their compensation in salary and total cash. Larger firms pay their CFOs higher proportion in bonus and non-cash, but less proportion in salary and cash compensation. As expected, CFOs of firms with high M/B ratio got a greater percentage of their remuneration in non-cash component. In addition, we find a positive relationship between the structure of CFO compensation and firm performance. The Stock Returns variable is signif- 
icantly positive for the proportion of bonus, while the $R O A$ variable is significantly positive for the proportion of salary and total cash compensation.

\subsubsection{Earnings management}

Table 7 shows the results of model (2) which tests the association of CFO gender and earnings quality. The first two columns in Table 7 display the results of accruals management $(A M)$ and the last two columns exhibit the results of real transactions management (RTM).

[Insert Table 7]

It is clear from Table 7 that the coefficients of Female CFOs variable are significantly negative for all measures of earnings management. It indicates that firms with female CFOs engage significantly less in accruals-based earnings management and real activities manipulation. The result of accruals management is similar to the US evidence (Peni \& Vahamaa 2010, Barua et al. 2010). Consistent with the literature on gender-based differences, our results show that female CFOs are more conservative and firms with female CFOs use significantly less earnings management relative to firms with male CFOs. Our finding provides supporting evidence that female CFOs delivery higher quality of earnings than their male counterparts.

Our coefficient estimates for the control variables in Table 7 are in line with prior studies. For example, the coefficients of Total Assets and Female Dir. Board variables are significantly negative for $A M$ and are consistent with Kothari et al. (2005) and Srinidhi et al. (2011). Smaller firms or firms with female board participation are more likely to have higher accruals quality. The CFO Ownership variable is positive and statistically significant across both measures of earnings management, implying that the higher the CFO stock ownership, the more likely firms engage in all types of earnings management. The Std dev (Sales/TA) is significantly negative with the RTM measure, indicating that firms with higher volatility in sales are less likely to involve in real transactions manipulation.

\subsubsection{Robustness test: matched firms using the propensity matching score method}

Given the large disparity in the number of firms with male and female CFOs, we conduct an additional analysis using the propensity-score matching approach adopted by Armstrong et al. (2010). This approach also addresses the potential selection bias of female CFOs not being randomly assigned to firms. The probability of a firm having a female CFO is modeled using 
a logistic regression with both firm size (Sales) and firm leverage as the independent variables. We include these two variable as the results Table 3 shows that there is a difference of financial characteristics across the gender of CFOs in firm size and firm leverage. Industry and year effects are also controlled for in the logit regression. We then use the propensity scores obtained from the logistic regression and perform a one-to-one nearest neighbor match with replacement. This procedure is to ensure that each female CFO firm is paired with a male CFO firm in the same industry and year with the lowest difference in propensity scores. The caplier distance of 0.10 is imposed when we do the match, i.e. the control and treatment firms' propensity scores are allowed to differ by up to 0.10. We pool the treatment sample (female CFOs) and the matched sample (male CFOs) together and have 82 observations for compensation sample and 62 observations for earnings management sample.

It is found that there is no significant difference in firm size and leverage, by construction, between firms with female and male CFOs in the matched samples. Furthermore, the significant differences between male and female CFOs for MBA Qualification, Board Size and Insider Ratio variables in the original sample are no longer apparent in the matched sample. The similarity of control variables across gender indicates that the propensity score matching procedure has been successful in matching firms with male and female CFOs across multiple dimensions (Rosenbaum \& Rubin 1985). In addition, Sianesi (2004) suggests another method to assess the matching quality is to re-estimate the probit regression for propensity matching on the matched sample. The pseudo- $R^{2}$ and F-test on the joint significance of all regressors before and after matching are then compared. After the matching there should be no systematic differences in the distributions of the covariates and the pseudo- $R^{2}$ should be low. In our case, the pseudo- $R^{2}$ changes from approximately $10 \%$ before the matching procedure to $1 \%$ after the match. In addition, the regression F-test which is not rejected before the matching is rejected after the match. ${ }^{17}$ This further indicates that our propensity matching procedure is successful in matching male and female CFOs.

We replicate the regressions of Tables 4, 5, 6 and 7 using the propensity score matched samples. It is found that the coefficients of the Female CFOs variable in Table 4 and 5 are still negative, but insignificant in all measures of compensation. It indicates that female CFOs still earn less than male CFOs in the matched sample, but the difference is not statistically significant at the conventional levels. However, if looking at the magnitude of the coefficients, it is arguable

\footnotetext{
${ }^{17}$ The $\mathrm{p}$-value of the F-test is 0.0048 for the original sample while its value becomes 0.9998 for the matched sample.
} 
that the coefficients of the Female CFOs variable are economically large. For example, in the matched sample, female CFOs receive approximately $\$ 100,000$ less in bonus, $\$ 55,000$ less in salary and $\$ 160,000$ less in total compensation than their male peers. The results for Table 6 and 7 with the matched sample are unchanged. Female CFOs are more cautious and they choose to have less-risky compensation packages with more salary, less bonus and less non-cash component compared to their male counterparts. They also less engage in all types of earnings management than male CFOs.

\subsection{Discussion of results}

Our empirical analysis shows that female CFOs only account for a small proportion (7.37\%) of firms in our sample and they generally work in small firms. This is vastly different from the US where female and male CFOs work in firms of similar size (Barua et al. 2010). It is possible that gender discrimination explains, at least partially, the small fraction of women compared to men who become CFOs in the Australian exchange-listed firms. Consistent with the documented gender pay gap internationally, it is also found that there is a gender disparity in Australian CFO compensation. Overall, female CFOs earn significantly less than their male counterparts in all types of remuneration even though they have obtained similar qualifications. In addition, the company accounting and stock market performance are not significantly impacted by CFO gender. Although female CFOs earn much less than their male counterparts, our results show that female CFOs are more conservative and delivery better reporting quality. Compared to firms with male CFOs, firms with female CFOs have significant lower accruals-based earnings managemen and real activities manipulation.

The result of no gender pay gap in the propensity score setting suggests that the gender differences in CFO pay is possibly due to the firm size effect as larger firms tend to reward their executives more than smaller firms (Smith \& Watts 1992, Bedard et al. 2014, Duong \& Evans 2015). Women may choose to work in smaller firms for other reasons. It is often believed that social and family pressures may exert influence in limiting the workforce mobility of women. Lam \& Dreher (2004) argue that an executive gender pay gap may not be so much an issue of labor market discrimination but rather family pressures that limit women's work choices. Women may only consider high-level positions when they are able to match the work commitment with family life. This may result in a female executive intentionally sacrificing personal salary enhancement in favor of family convenience (Lam et al. 2013). Similarly, Gayle et al. 
(2012) claim that the higher exit rate for female executives could be another factor in explaining the executive gender pay gap. Although female executives are most commonly beyond childbearing age, there is evidence that such women are more likely to exit the firm for personal or family-related reasons than their male peers (Sicherman 1996).

Our results also show that female CFOs choose less risky compensation packages than their male counterparts. We find that female CFOs are compensated more by cash and less by non-cash component. In addition, female CFOs receive more salary and fewer bonuses, as a proportion to total compensation, compared to male CFOs. Graham et al. (2013) observe that managers choose the compensation package according to their personal risk preference. Agency theory predicts a fundamental trade-off between risk and incentives. From an optimal contract perspective, the amount of risk that executives bear and their expected wage payment depends on their risk attitudes (Grossman \& Hart 1983). Risk-taking managers are, consequently, much more likely to be paid with proportionately more stocks, options, bonuses and much less likely to be compensated via salary. As risk aversion is an inherent trait of female CFOs, this explains why female CFOs tend to have less equity-based compensation contracts.

Beside compensation structures, the gender-based difference in risk attitudes could potentially play a role in justifying the different behavior of CFOs towards earnings management. We find firms with female CFOs report significantly lower accruals-based and real-based earnings management. It suggests that female CFOs are more cautious in the real activities manipulation due to its potential damages to the long-run firm value. Our finding is consistent with a recent study of Francis et al. (2015) that risk aversion of female CFOs could impact accounting conservatism and female CFOs adopt more conservative accounting practices than their male counterparts.

\section{Conclusion}

Increasing business complexity and recent economic shocks have acted to elevate the importance and significance of the role of CFOs in organizations. It is therefore essential to further explore and investigate attributes, characteristics and skill sets of CFOs. The primary objective of this paper is to focus in on one such characteristic, namely CFO gender, and examine how it affects CFO remuneration and earnings quality.

The results in our paper indicate a gender pay disparity between male and female CFOs. Fe- 
male CFOs are not only paid less than male CFOs but are also totally unrepresented in a large number of industry groupings. In an era where the majority of graduates from Australian Business Schools are female, these findings raise a number of questions. Our findings articulate the very strong preponderance of female CFOs in small and medium enterprises (SMEs), and this explains why the CFO gender pay gap dissipates in the propensity score matching method. We also show that firms with female CFOs incur less debt than those firms with male CFOs but other characteristics, such as, M/B ratio, company performance and qualifications held by female CFOs are similar to those of male CFOs. One inference of this is that we are able to eliminate two possible reasons for female pay inequity, namely, qualification differentials and differing company performance levels.

Our findings also provide some insights into different pay components between male and female CFOs. Female CFOs receive a larger proportion of their pay in cash, have smaller bonus payments and are highly represented in the consumer stables and finance industry groupings. Although female CFOs receive lower remuneration compared to male CFOs, they add value to corporations by having higher reporting quality. We find that female CFOs are more conservative in both accruals-based and real-based earnings management. Due likely to the risk attitudes of females, there is a gender effect in CFO compensation and earnings quality.

\section{Acknowledgement}

The authors would like to acknowledge the Accounting and Finance Association of Australia and New Zealand (AFFANZ), School of Accounting and Curtin Business School for research grants to support this project. We are grateful for insightful comments and suggestions made by an anonymous referee, Grantley Taylor, Chloe Ho and 2016 AFAANZ conference delegates. The research assistance provided by Hanh Tran and Nargess Golshan is also acknowledged. 


\section{References}

Adams, R. \& Ferreira, D. (2009), 'Women in the Boardroom and Their Impact on Governance and Performance', Journal of Financial Economics 94(2), 291-309.

Agnew, J., Balduzzi, P. \& Sunden, A. (2003), 'Portfolio Choice and Trading in a Large 401(K) Plan', The American Economic Review 93(1), 193-215.

Armstrong, C., Ittner, C. \& Larcker, D. (2010), 'Chief Executive Officer Equity Incentives and Accounting Irregularities', Journal of Accounting Research 48(2), 225-271.

Badertscher, B. A. (2011), 'Overvaluation and the Choice of Alternative Earnings Management Mechanisms', The Accounting Review 86(5), 1149-1518.

Baldry, J. C. (1987), 'Income Tax Evasion and the Tax Schedule', Public Finance 42, 357-383.

Balsam, S., Irani, A. J. \& Yin, Q. J. (2012), 'Impact of Job Complexity and Performance on CFO Compensation', Accounting Horizons 26(3), 395-416.

Banghoj, J., Gabrielsen, G., Petersen, C. \& Plenborg, T. (2010), 'Determinants of Executive Compensation in Privately Held Firms', Accounting and Finance 50(3), 481-510.

Barua, A., Davidson, L. F., Rama, D. V. \& Thiruvadi, S. (2010), 'CFO Gender and Accruals Quality', Accounting Horizons 24(1), 25-39.

Bedard, J. C., Hoitash, R. \& Hoitash, U. (2014), 'Chief Financial Officers as Inside Directors', Contemporary Accounting Research 31(3), 787-817.

Bertrand, M. \& Hallock, K. (2001), 'The Gender Gap in Top Corporate Jobs', Industrial and Labor Relations Review 55(1), 3-21.

Betz, M., O'Connell, L. \& Shepard, J. M. (1989), 'Gender Differences in Proclivity for Unethical Behavior', Journal of Business Ethics 8(5), 321-324.

Bugeja, M., da Silva Rosa, R., Duong, L. \& Izan, H. (2012), 'CEO Compensation from M\&As in Australia', Journal of Business Finance \& Accounting 39(9), 1298-1329.

Bugeja, M., Matolcsy, Z. P. \& Spiropoulos, H. (2012), 'Is There a Gender Gap in CEO Compensation?', Journal of Corporate Finance 18(4), 849-859.

Byrnes, J. O., Miller, D. C. \& Schafer, W. D. (1999), 'Gender Differences in Risk Taking', Psychological Bulletin 125, 367-383.

Carter, D. A., Simkins, B. J. \& Simpson, W. G. (2003), 'Corporate Governance, Board Diversity and Firm Value', Financial Review 38(1), 33-53.

Chalmers, K., Koh, P. \& Stapledon, G. (2006), 'The Determinants of CEO Compensation: Rent Extraction or Labor Demand?', The British Accounting Review 38(3), 259-275.

Cohen, D. A., Dey, A. \& Lys, T. Z. (2008), 'Real and Accrual Based Earnings Management in the Pre and Post Sarbanes Oxley Periods', The Accounting Review 83(3), 757-787.

Daily, C. M., Certo, S. T. \& Dalton, D. R. (1999), 'A Decade of Corporate Women: Some Progress in the Boardroom, None in the Executive Suite', Strategic Management Journal 20(1), 93-99.

Dechow, P. M. \& Dichev, I. D. (2002), 'The Quality of Accruals and Earnings: The Role of Accrual Estimation Errors', The Accounting Review 77(1), 35-39. 
Dhaliwal, D. S., Naiker, V. \& Navissi, F. (2010), 'The Association between Accruals Quality and the Characteristics of Accounting Experts and Mix of Expertise on Audit Committees', Contemporary Accounting Research 27(3), 787-827.

Duong, L. \& Evans, J. (2015), 'CFO Compensation: Evidence from Australia', Pacific-Basin Finance Journal 35(Part A), 425-443.

Ferreira, N., Matos, P. \& Murphy, K. J. (2013), 'Are U.S. CEOs Paid More? New International Evidence', The Review of Financial Studies 26(2), 323-367.

Francis, B., Hasan, I., Park, J. C. \& Wu, Q. (2015), 'Gender Differences in Financial Reporting Decision-making: Evidence from Accounting Conservatism', Contemporary Accounting Research 32(3), 1285-1318.

Gayle, G., Golan, L. \& Miller, R. (2012), 'Gender Differences in Executive Compensation and Job Mobility', Journal of Labour Economics 30(4), 829-871.

Ge, W., Matsumoto, D. \& Zhang, J. L. (2011), 'Do CFOs Have Style? An Empirical Investigation of the Effect of Individual CFOs on Accounting Practices', Contemporary Accounting Research 28(4), 1141-1179.

Geiger, M. \& North, D. (2006), 'Does Hiring a New CFO Change Things? An Investigation of Changes in Discretionary Accruals', The Accounting Review 81(4), 781-809.

Graham, J. R., Harvey, C. H. \& Puri, M. (2013), 'Managerial Attitudes and Corporate Actions', Journal of Financial Economics 109(1), 103-121.

Graham, J. R., Harvey, C. R. \& Rajgopal, S. (2005), 'The Economic Implications of Corporate Financial Reporting', Journal of Accounting and Economics 40(1), 3-73.

Grossman, S. \& Hart, O. (1983), 'An Analysis of the Principal Agent Problem', Econometrica $\mathbf{5 1}(1), 7-45$.

Hogg, M. A. \& Terry, D. J. (2000), 'Social Identity and Self-categorization Process in Organizational Contexts', Academy of Management Review 25(1), 121-140.

Hoitash, R., Hoitash, U. \& Johnstone, M. (2012), 'Internal Control Material Weakness and CFO Compensation', Contemporary Accounting Research 29(3), 768-803.

Huang, H. \& Kisgen, D. (2013), 'Gender and Corporate Finance: Are Male Executives Overconfident Relative to Female Executives?', Journal of Financial Economics 108(3), 822-839.

Jiang, J. X., Petroni, K. R. \& Wang, I. Y. (2010), 'CFOs and CEOs: Who Have the Most Influence on Earnings Management', Journal of Financial Economics 96(3), 513-526.

Jordan, C., Clark, S. \& Wardon, M. (2007), 'Gender Bias and Compensation in the Executive Suite', Journal of Organizational Culture, Communications and Conflict 11(1), 19-29.

Kothari, S., Leone, A. \& Wasley, C. (2005), 'Performance Matched Discretionary Measures', Journal of Accounting and Economics 39(1), 163-197.

Kulich, C., Trojanowski, G., Ryan, M. K., Haslam, S. A. \& Renneboog, L. D. R. (2011), 'Who Gets the Carrot and Who gets the Stick? Evidence of Gender Disparities in Executive Compensation', Strategic Management Journal 32(3), 301-321.

Labelle, R., Gargouri, R. M. \& Francoeur, C. (2010), 'Ethics, Diversity Management, and Financial Reporting Quality', Journal of Business Ethics 93(2), 335-353. 
Lam, K. C., McGuinness, P. B. \& Vieito, J. P. (2013), 'CEO Gender, Executive Compensation and Firm Performance in Chinese-listed Enterprises', Pacific-Basin Finance Journal 21(1), 1136-1159.

Lam, S. S. \& Dreher, G. E. (2004), 'Gender, Extra-Firm Mobility and Compensation Attainment in the United States and Hong Kong', Journal of Organizational Behavior 25(7), 791-805.

Lenney, E. (1977), 'Women's Self-confidence in Achievement Settings', Psychological Bulletin 84(1), 1-13.

Levi, M., Li, K. \& Zhang, F. (2014), 'Director Gender and Mergers and Acquisitions', Journal of Corporate Finance 28, 185-200.

Low, D. C. M., Roberts, H. \& Whiting, R. H. (2015), 'Board Gender Diversity and Firm Performance: Empirical Evidence from Hong Kong, South Korea, Malaysia and Singapore', Pacific-Basin Finance Journal 35(Part A), 381-401.

Loyeung, A. \& Matolcsy, Z. (2015), 'CFO's Accounting Talent, Compensation and Turnover', Accounting and Finance 55(4), 1105-1134.

Menon, K. \& Williams, D. D. (2004), 'Former Audit Partners and Abnormal Accruals', The Accounting Review 79(4), 1095-1118.

Munoz-Bullon, F. (2010), 'Gender-Compensation Differences among High-Level Executives in the United States', Industrial Relations 49(3), 346-370.

Murphy, K. J. (1985), 'Corporate Performance and Managerial Remuneration: An Empirical Analysis', Journal of Accounting and Economics 7(1-3), 11-42.

Peni, E. \& Vahamaa, S. (2010), 'Female Executives and Earnings Management', Managerial Finance 36(7), 629-645.

Petersen, M. A. (2009), 'Estimating Standard Errors in Finance Panel Data Sets: Comparing Approaches', The Review of Financial Studies 22(1), 435-480.

Powell, G. N. (1999), Reflections on the Glass Ceiling. In Handbook of Gender and Work, Powell, G.N. (ed), SAGE, London, UK, 325-345.

Riley, W. B. \& Chow, K. V. (1992), 'Asset Allocation and Individual Risk Aversion', Financial Analyst Journal 48(6), 32-37.

Rogers, W. (1993), 'Regression Standard Errors in Clustered Samples', Stata Technical Bulletin 13, 19-23.

Rosenbaum, P. R. \& Rubin, D. B. (1985), 'Constructing a Control Group using Multivariate Matched Sampling Methods that Incorporate the Propensity Score', The American Statistician 39(1), 33-38.

Rosenstein, S. \& Wyatt, J. G. (1990), 'Outside Directors, Board Independence, and Shareholder Wealth', Journal of Financial Economics 26(2), 175-191.

Roychowdhury, S. (2006), 'Earnings Management through Real Activities Manipulations', Journal of Accounting and Economics 42(3), 335-370.

Shin, T. (2012), 'The Gender Gap in Executive Compensation: The Role of Female Directors and Chief Executive Officers', The Annals of the American Academy of Political and Social Science 639(1), 258-278. 
Sianesi, B. (2004), 'An Evaluation of the Swedish System of Active Labor Market Programs in the 1990s', The Review of Economics and Statistics 86(1), 133-155.

Sicherman, N. (1996), 'Gender Differences in Departures from a Large Firm', Industrial and Labor Review 49(3), 484-505.

Smith, C. W. \& Watts, R. L. (1992), 'The Investment Opportunity Set and Corporate Financing, Dividend, and Compensation Policies', Journal of Financial Economics 32(3), 263-292.

Srinidhi, B., Gul, F. A. \& Tsui, J. (2011), 'Female Directors and Earnings Quality', Contemporary Accounting Research 28(5), 1610-1644.

Sunden, A. \& Surette, B. (1998), 'Gender Differences in the Allocation of Assets in Retirement Savings Plans', The American Economic Review 88(2), 207-211.

Vieito, J. P. \& Khan, W. A. (2012), 'Executive Compensation and Gender: S\&P 1500 Listed Firms', Journal of Economics and Finance 36(2), 371-399.

Wang, W., Shin, Y. \& Francis, B. B. (2012), 'Are CFOs' Trades More Informative Than CEOs' Trades?', Journal of Financial and Quantitative Analysis 47(4), 743-762.

Wang, W. \& Wang, X. (2014), 'Predicting Earnings in a Poor Information Environment', Journal of Contemporary Accounting \& Economics 10(1), 46-58.

Wilson, M. (2011), 'Earnings Management in Australian Corporations', Australian Accounting Review 21(3), 205-221.

Yermack, D. (1996), 'Higher Market Valuation of Companies with a Small Board of Directors', Journal of Financial Economics 40(1), 185-211.

Zang, A. Y. (2012), 'Evidence on the Trade-Off between Real Activities Manipulations and Accrual-Based Earnings Management', The Accounting Review 87(2), 675-703. 
Table 1: Variable definitions.

\begin{tabular}{|c|c|}
\hline Variables & Definition \\
\hline \multicolumn{2}{|c|}{ CFO compensation [Data source: Capital IQ database] } \\
\hline Salary & The sum of salary and superannuation paid to the CFO during the year. \\
\hline Bonus & Bonus paid to the $\mathrm{CFO}$ in the year. \\
\hline Total Cash Comp. & The sum of salary, bonus and other cash compensation paid to the CFO. \\
\hline Total Non-cash Comp. & $\begin{array}{l}\text { Total value of restricted stock rewards and stock options awards granted to the CFO } \\
\text { as part of their remuneration package. }\end{array}$ \\
\hline Total Comp. & Total compensation, calculated as the sum of cash and non-cash component. \\
\hline \multicolumn{2}{|c|}{ CFO compensation structure } \\
\hline Prop. Salary & The proportion of CFO salary to their total compensation. \\
\hline Prop. Bonus & The proportion of CFO bonus to their total compensation. \\
\hline Prop. Cash & The proportion of CFO cash compensation to their total compensation. \\
\hline Prop. Non-cash & The proportion of CFO non-cash compensation to their total compensation. \\
\hline \multicolumn{2}{|c|}{ Earnings management [Data source: FinAnalysis database] } \\
\hline$A M$ & $\begin{array}{l}\text { The amount of accruals management, which is proxied by accrual estimator errors. It } \\
\text { is calculated as the absolute value of residuals using the method of } \\
\text { Dechow \& Dichev (2002). }\end{array}$ \\
\hline$R T M$ & $\begin{array}{l}\text { The amount of real transactions management, which is the sum of the absolute value } \\
\text { of abnormal operating cash flows and abnormal capital expenditures using the } \\
\text { method of Zang (2012). }\end{array}$ \\
\hline
\end{tabular}

Financial characteristics [Data source: FinAnalysis database]

Sales Natural logarithm of gross sales figure after credit and returns in prior year.

Leverage The firm financial leverage, calculated as total debt divided by market value of equity in the previous year.

$M / B$ Ratio $\quad$ The market value of equity divided by the book value of equity.

ROA Earnings before tax divided by total assets in the prior year.

Stock Returns The unadjusted return on company's shares during the year, calculated as the current year share price divided by the previous share price, expressed in logarithm.

Total Assets

Prop. Loss Years

Std dev (Sales/TA)

Natural logarithm of total assets in prior year.

The proportion of years that a company made loss over the previous 6 years.

Std dev $(C F / T A) \quad$ Standard deviation of operating cash flows divided by total assets over the last 5 years.

Governance and CFO characteristics [Data source: Capital IQ, FinAnalysis database \& annual reports]

Female CFOs MBA Qualification

CFO Board

$\%$ Female Board

$\%$ Female Remu.

CFO Ownership

CFO Tenure

Board Size

Insider Ratio

AC Size

PAFE
An indicator variable coded as one if the CFO of company is female, zero otherwise. An indicator variable coded as one if the company CFO has an MBA degree, zero otherwise.

An indicator variable coded as one if the CFO is on the company board of directors, zero otherwise.

The percentage of female directors on the company board.

The percentage of female directors on the remuneration committee.

The percentage of company shares owned by the CFO.

The number of years since the CFO was appointed.

The number of directors on the board of directors.

The percentage of executive directors on the board.

The number of directors on the audit committee.

The percentage of audit committee members who have financial accounting expert, i,e. the biography states one of the followings: CA/CPA, auditor, controller, treasurer or finance managers. 
Table 2: Sample industry - separated between female and male CFOs firms.

\begin{tabular}{lcccc} 
Industry & No. of firms & Female CFOs & Male CFOs & Percentage of female CFOs \\
\hline & & & & \\
Consumer Discretionary & 53 & 4 & 49 & $7.55 \%$ \\
Consumer Staples & 32 & 3 & 29 & $9.38 \%$ \\
Energy & 66 & 10 & 56 & $1.52 \%$ \\
Financials & 97 & 9 & 88 & $9.28 \%$ \\
Healthcare & 50 & 2 & 48 & $4.00 \%$ \\
Industrials & 88 & 3 & 85 & $3.41 \%$ \\
Information Technology & 17 & 0 & 17 & $0 \%$ \\
Materials & 134 & 10 & 124 & $7.46 \%$ \\
Telecommunications & 13 & 0 & 13 & $0 \%$ \\
Utilities & 6 & 0 & 6 & $0 \%$ \\
& & & & $\mathbf{5 1 5}$ \\
Total & $\mathbf{5 5 6}$ & $\mathbf{4 1}$ & $\mathbf{5 1 5}$ \\
\hline
\end{tabular}


Table 3: Descriptive statistics.

Panel A: CFO Gender and CFO compensation

\begin{tabular}{|c|c|c|c|c|c|c|c|c|c|c|c|}
\hline & \multirow{2}{*}{\multicolumn{3}{|c|}{$\begin{array}{l}\text { Pooled sample } \\
\quad \mathrm{N}=556\end{array}$}} & \multirow{2}{*}{\multicolumn{3}{|c|}{$\begin{array}{c}\text { Female CFOs } \\
\mathrm{N}=41\end{array}$}} & \multirow{2}{*}{\multicolumn{3}{|c|}{$\begin{array}{l}\text { Male CFOs } \\
\mathrm{N}=515\end{array}$}} & \multicolumn{2}{|c|}{ Diff. in mean/median } \\
\hline & & & & & & & & & & & Mann-Whitney \\
\hline & Mean & Median & Std dev & Mean & Median & Std dev & Mean & Median & Std dev & t-stat & stat \\
\hline \multicolumn{12}{|c|}{ CFO compensation $(\$)$} \\
\hline Salary & 470,608 & 364,299 & 302,731 & 317,746 & 275,229 & 177,550 & 482,778 & 375,000 & 307,393 & $-3.39 * * *$ & $3.45 * * *$ \\
\hline Bonus & 284,008 & 100,000 & 462,893 & 75,908 & 14,100 & 126,564 & 300,575 & 114,876 & 475,800 & $-3.01 * * *$ & $3.92^{* *}$ \\
\hline Total Cash Comp. & 895,894 & 532,455 & 973,429 & 474,718 & 340,536 & 339,504 & 929,425 & 556,413 & 999,451 & $-2.90^{* * *}$ & $3.75^{* * *}$ \\
\hline Total Non-cash Comp. & 259,696 & 83,426 & 558,985 & 91,710 & 35,458 & 114,274 & 273,070 & 90,058 & 577,877 & $-2.01^{* *}$ & $2.04^{* *}$ \\
\hline Total Comp. & $1,155,591$ & 665,629 & $1,1317,673$ & 566,428 & 383,557 & 402,132 & $1,202,495$ & 696,825 & $1,353,617$ & $-2.99 * * *$ & $3.55^{* * *}$ \\
\hline \multicolumn{12}{|c|}{ Structure of CFO compensation (as \% to total compensation) } \\
\hline Prop. Bonus & $16.54 \%$ & $16.84 \%$ & $15.35 \%$ & $12.10 \%$ & $4.03 \%$ & $11.10 \%$ & $18.21 \%$ & $17.72 \%$ & $15.45 \%$ & $-3.70^{* * *}$ & $3.73^{* * *}$ \\
\hline Prop. Salary & $57.54 \%$ & $55.29 \%$ & $25.63 \%$ & $65.32 \%$ & $68.76 \%$ & $18.85 \%$ & $56.50 \%$ & $53.70 \%$ & $26.00 \%$ & $2.12^{* *}$ & $3.14^{* * *}$ \\
\hline Prop. Cash & $84.14 \%$ & $86.83 \%$ & $27.29 \%$ & $86.60 \%$ & $88.07 \%$ & $14.32 \%$ & $83.10 \%$ & $84.75 \%$ & $28.07 \%$ & $1.69^{*}$ & $1.66^{*}$ \\
\hline Prop. Non-cash & $14.86 \%$ & $13.18 \%$ & $27.28 \%$ & $12.65 \%$ & $11.94 \%$ & $14.03 \%$ & $15.84 \%$ & $14.25 \%$ & $15.56 \%$ & $-1.68^{*}$ & $1.65^{*}$ \\
\hline \multicolumn{12}{|c|}{ Financial characteristics } \\
\hline Sales (\$mil) & 3,589 & 505 & 8,646 & 991 & 64 & 2,314 & 3,796 & 559 & 8,929 & $-2.01 * *$ & $3.71^{* * *}$ \\
\hline Leverage & 0.47 & 0.49 & 0.26 & 0.38 & 0.34 & 0.28 & 0.48 & 0.49 & 0.27 & $-2.28^{* *}$ & $2.18^{* *}$ \\
\hline M/B Ratio & 3.48 & 2.30 & 4.46 & 3.40 & 1.97 & 4.29 & 3.49 & 2.31 & 4.48 & -0.12 & 0.90 \\
\hline $\mathrm{ROA}$ & $3.70 \%$ & $6.50 \%$ & $19.36 \%$ & $0.91 \%$ & $4.02 \%$ & $18.38 \%$ & $3.92 \%$ & $6.59 \%$ & $19.43 \%$ & -0.96 & 1.58 \\
\hline Stock Returns & $7.44 \%$ & $8.79 \%$ & $59.73 \%$ & $4.39 \%$ & $0.96 \%$ & $54.23 \%$ & $7.69 \%$ & $9.16 \%$ & $60.18 \%$ & -0.34 & 0.30 \\
\hline \multicolumn{12}{|c|}{ Governance and CFO characteristics } \\
\hline CFO Female & $7.37 \%$ & & & & & & & & & & \\
\hline MBA Qual. & $20.50 \%$ & & & $26.89 \%$ & & & $20.00 \%$ & & & 1.04 & \\
\hline CFO Board & $43.08 \%$ & & & $31.71 \%$ & & & $54.98 \%$ & & & $\mathbf{- 2 . 7 6} * * *$ & \\
\hline$\%$ Female Board & $6.49 \%$ & $0 \%$ & $8.58 \%$ & $9.73 \%$ & $11.11 \%$ & $9.71 \%$ & $6.36 \%$ & $0 \%$ & $8.45 \%$ & $2.52^{* *}$ & $2.24^{* *}$ \\
\hline \%Female Rem. & $8.13 \%$ & $0 \%$ & $14.14 \%$ & $6.99 \%$ & $0 \%$ & $15.20 \%$ & $8.22 \%$ & $0 \%$ & $14.08 \%$ & -0.50 & 0.63 \\
\hline CFO Ownership & $0.21 \%$ & $0.03 \%$ & $0.64 \%$ & $0.68 \%$ & $0.07 \%$ & $1.52 \%$ & $0.17 \%$ & $0.03 \%$ & $0.50 \%$ & $4.98^{* * *}$ & $1.95^{*}$ \\
\hline CFO Tenure (years) & 5.26 & 4.17 & 3.86 & 4.02 & 2.92 & 3.25 & 5.36 & 4.33 & 3.89 & $-2.14^{* *}$ & $2.39^{* *}$ \\
\hline Board size & 7.08 & 8.00 & 2.59 & 6.32 & 6.00 & 1.65 & 7.92 & 8.00 & 2.61 & $-3.87^{* * *}$ & $4.11^{* * *}$ \\
\hline Insider ratio & $39.49 \%$ & $37.50 \%$ & $15.76 \%$ & $48.53 \%$ & $50.00 \%$ & $21.51 \%$ & $38.77 \%$ & $37.50 \%$ & $15.01 \%$ & $3.86^{* * *}$ & $3.01^{* * *}$ \\
\hline
\end{tabular}

continued on next page 
continued from previous page

Panel B: CFO Gender and Earnings Management

\begin{tabular}{|c|c|c|c|c|c|c|c|c|c|c|c|}
\hline & \multicolumn{3}{|c|}{$\begin{array}{c}\text { Pooled sample } \\
\mathrm{N}=437\end{array}$} & \multicolumn{3}{|c|}{$\begin{array}{c}\text { Female CFOs } \\
\mathrm{N}=31\end{array}$} & \multicolumn{3}{|c|}{$\begin{array}{c}\text { Male CFOs } \\
\mathrm{N}=406\end{array}$} & \multicolumn{2}{|c|}{$\begin{array}{c}\text { Diff. in mean/median } \\
\text { Mann-Whitney }\end{array}$} \\
\hline & Mean & Median & Std dev & Mean & Median & Std dev & Mean & Median & Std dev & t-stat & stat \\
\hline \multicolumn{12}{|c|}{ Earnings management } \\
\hline $\mathrm{AM}$ & 0.061 & 0.032 & 0.097 & 0.052 & 0.021 & 0.049 & 0.067 & 0.043 & 0.099 & -0.80 & $1.94^{*}$ \\
\hline RTM & 0.244 & 0.160 & 0.425 & 0.186 & 0.158 & 0.149 & 0.249 & 0.161 & 0.439 & $-1.83^{*}$ & 0.21 \\
\hline \multicolumn{12}{|c|}{ Financial characteristics } \\
\hline Total Assets (\$mil) & 7,403 & 704 & 21,259 & 1,267 & 192 & 2,404 & 7,872 & 827 & 21,977 & $-1.67^{*}$ & $2.91^{* * *}$ \\
\hline Prop. Loss Years & 0.23 & 0 & 0.36 & 0.40 & 0.17 & 0.08 & 0.21 & 0 & 0.35 & $2.86^{* * *}$ & $2.13^{* *}$ \\
\hline Std dev (Sales/TA) & 0.22 & 0.14 & 0.52 & 0.14 & 0.11 & 0.13 & 0.23 & 0.15 & 0.54 & -0.82 & 1.07 \\
\hline Std dev $(\mathrm{CF} / \mathrm{TA})$ & 0.13 & 0.06 & 0.27 & 0.08 & 0.05 & 0.10 & 0.14 & 0.06 & 0.28 & -1.16 & 0.96 \\
\hline \multicolumn{12}{|c|}{ Governance characteristics } \\
\hline AC Size & 3.47 & 3.00 & 0.92 & 3.16 & 3.00 & 0.82 & 3.50 & 3.00 & 0.92 & $-1.97^{* *}$ & 1.57 \\
\hline PAFE & 0.54 & 0.50 & 0.27 & 0.55 & 0.67 & 0.28 & 0.54 & 0.50 & 0.27 & 0.25 & 0.28 \\
\hline
\end{tabular}

This table presents summary statistics of firms in our sample for the years 2006 to 2010. Panel A is for CFO compensation and Panel B is for earnings management. It is reported for the whole sample and also partitioned by gender. All variables are defined in Table 1 . Tests for difference in mean and median of each variable in the two sub-samples are displayed in the table. Bold figures show that there is a significant difference (at the significance level of $10 \%$ or better) between the two sub-samples. *, **, or *** indicate statistical significance at the $10 \%, 5 \%$ or $1 \%$ level respectively. 
Table 4: Regression results on CFO compensation (compensation in \$'000).

Panel A: Bonus and Non-cash compensation (\$'000) - Tobit regression

\begin{tabular}{|c|c|c|c|c|}
\hline & Bonus & Bonus & Non-cash & Non-cash \\
\hline Female CFOs & $\begin{array}{c}-129.98^{*} \\
{[-1.66]}\end{array}$ & $\begin{array}{c}-170.77^{*} \\
{[-1.72]}\end{array}$ & $\begin{array}{c}-156.49^{* *} \\
{[-1.96]}\end{array}$ & $\begin{array}{c}-180.66^{*} \\
{[-1.82]}\end{array}$ \\
\hline MBA Qualification & $\begin{array}{c}182.32^{* * *} \\
\quad[3.40]\end{array}$ & $\begin{array}{c}188.49^{* * *} \\
{[3.54]}\end{array}$ & $\begin{array}{c}153.61^{* *} \\
{[2.26]}\end{array}$ & $\begin{array}{c}163.59^{* * *} \\
{[2.42]}\end{array}$ \\
\hline CFO Board & $\begin{array}{l}-19.83 \\
{[-0.40]}\end{array}$ & $\begin{array}{l}-12.13 \\
{[-0.25]}\end{array}$ & $\begin{array}{l}74.55 \\
{[1.19]}\end{array}$ & $\begin{array}{l}72.62 \\
{[1.16]}\end{array}$ \\
\hline CFO Ownership & $\begin{array}{l}-25.25 \\
{[-0.41]}\end{array}$ & $\begin{array}{l}-22.26 \\
{[-0.36]}\end{array}$ & $\begin{array}{l}62.58 \\
{[0.91]}\end{array}$ & $\begin{array}{l}77.90 \\
{[1.11]}\end{array}$ \\
\hline CFO Tenure (ln) & $\begin{array}{l}39.76 \\
{[1.27]}\end{array}$ & $\begin{array}{l}39.61 \\
{[1.29]}\end{array}$ & $\begin{array}{l}-57.95 \\
{[-1.47]}\end{array}$ & $\begin{array}{l}-55.65 \\
{[-1.42]}\end{array}$ \\
\hline$\%$ Female Board & $\begin{array}{l}83.12^{*} \\
{[1.72]}\end{array}$ & & $\begin{array}{c}674.64^{* *} \\
{[1.96]}\end{array}$ & \\
\hline$($ Female Board $) *($ Female CFOs $)$ & $\begin{array}{l}-55.78 \\
{[-0.26]}\end{array}$ & & $\begin{array}{c}-149.39 \\
{[-0.56]}\end{array}$ & \\
\hline \% Female Remu. & & $\begin{array}{l}472.67^{* * *} \\
\quad[2.91]\end{array}$ & & $\begin{array}{c}\mathbf{5 7 7 . 3 7 ^ { * * * }} \\
{[\mathbf{2 . 7 8}]}\end{array}$ \\
\hline$($ Female Remu.)*(Female CFOs) & & $\begin{array}{l}72.59 \\
{[0.42]}\end{array}$ & & $\begin{array}{l}21.83 \\
{[0.11]}\end{array}$ \\
\hline Board Size & $\begin{array}{c}28.42^{* * *} \\
{[2.53]}\end{array}$ & $\begin{array}{c}28.46^{* * *} \\
{[2.60]}\end{array}$ & $\begin{array}{c}87.64^{* * *} \\
{[6.68]}\end{array}$ & $\begin{array}{c}86.00^{* * *} \\
{[6.55]}\end{array}$ \\
\hline Insider Ratio & $\begin{array}{l}-95.92 \\
{[-0.54]}\end{array}$ & $\begin{array}{l}-39.36 \\
{[-0.22]}\end{array}$ & $\begin{array}{l}-65.14 \\
{[-0.30]}\end{array}$ & $\begin{array}{l}-34.51 \\
{[-0.16]}\end{array}$ \\
\hline Sales (ln) & $\begin{array}{c}81.45^{* * *} \\
{[7.30]}\end{array}$ & $\begin{array}{c}81.79^{* * *} \\
{[7.54]}\end{array}$ & $\begin{array}{c}93.31^{* * *} \\
{[7.08]}\end{array}$ & $\begin{array}{c}\text { 92.21*** } \\
{[7.03]}\end{array}$ \\
\hline Leverage & $\begin{array}{l}82.37 \\
{[0.67]}\end{array}$ & $\begin{array}{l}64.90 \\
{[0.53]}\end{array}$ & $\begin{array}{l}49.52 \\
{[0.32]}\end{array}$ & $\begin{array}{l}41.69 \\
{[0.27]}\end{array}$ \\
\hline M/B Ratio & $\begin{array}{c}2.52 \\
{[0.49]}\end{array}$ & $\begin{array}{c}0.70 \\
{[0.13]}\end{array}$ & $\begin{array}{l}11.55^{*} \\
{[1.80]}\end{array}$ & $\begin{array}{l}9.46^{*} \\
{[1.67]}\end{array}$ \\
\hline $\mathrm{ROA}$ & $\begin{array}{c}-132.79 \\
{[-1.00]}\end{array}$ & $\begin{array}{c}-114.64 \\
{[-1.09]}\end{array}$ & $\begin{array}{l}-54.13 \\
{[-0.35]}\end{array}$ & $\begin{array}{l}-69.58 \\
{[-0.45]}\end{array}$ \\
\hline Stock Returns & $\begin{array}{c}111.97^{* * *} \\
{[2.61]}\end{array}$ & $\begin{array}{c}119.13^{* * *} \\
{[2.79]}\end{array}$ & $\begin{array}{l}78.11^{*} \\
{[1.69]}\end{array}$ & $\begin{array}{l}85.28^{*} \\
{[1.65]}\end{array}$ \\
\hline $\begin{array}{l}\text { Include fixed effects? } \\
\text { (Industry \& Year) }\end{array}$ & Yes & Yes & Yes & Yes \\
\hline No. zero observations & 144 & 144 & 128 & 128 \\
\hline No. non-zero obs. & 412 & 412 & 428 & 428 \\
\hline Total observations & 556 & 556 & 556 & 556 \\
\hline
\end{tabular}

continued on next page 
continued from previous page

Panel B: Salary and Total compensation (\$'000) - OLS regression

\begin{tabular}{|c|c|c|c|c|}
\hline & Salary & Salary & Total comp. & Total comp. \\
\hline Female CFOs & $\begin{array}{c}-91.33^{* *} \\
{[-2.32]}\end{array}$ & $\begin{array}{c}-108.42^{* * *} \\
{[-2.88]}\end{array}$ & $\begin{array}{c}-271.04^{*} \\
{[-1.81]}\end{array}$ & $\begin{array}{c}-358.35^{* *} \\
{[-2.20]}\end{array}$ \\
\hline MBA Qualification & $\begin{array}{l}12.14 \\
{[0.36]}\end{array}$ & $\begin{array}{l}10.86 \\
{[0.32]}\end{array}$ & $\begin{array}{c}183.76 \\
{[0.90]}\end{array}$ & $\begin{array}{c}208.78 \\
{[0.99]}\end{array}$ \\
\hline CFO Board & $\begin{array}{c}96.60 * * * \\
{[2.97]}\end{array}$ & $\begin{array}{c}90.98^{* * *} \\
{[2.74]}\end{array}$ & $\begin{array}{c}227.65 \\
{[1.44]}\end{array}$ & $\begin{array}{c}208.45 \\
{[1.28]}\end{array}$ \\
\hline CFO Ownership & $\begin{array}{l}13.85 \\
{[0.57]}\end{array}$ & $\begin{array}{l}52.52 \\
{[1.54]}\end{array}$ & $\begin{array}{l}54.16 \\
{[0.75]}\end{array}$ & $\begin{array}{c}142.64 \\
{[1.45]}\end{array}$ \\
\hline CFO Tenure (ln) & $\begin{array}{l}-22.49 \\
{[-1.24]}\end{array}$ & $\begin{array}{l}-23.91 \\
{[-1.30]}\end{array}$ & $\begin{array}{c}-0.98 \\
{[-0.01]}\end{array}$ & $\begin{array}{c}7.84 \\
{[0.08]}\end{array}$ \\
\hline$\%$ Female Board & $\begin{array}{c}300.99 * \\
{[1.85]}\end{array}$ & & $\begin{array}{c}1,411.77^{* *} \\
{[2.12]}\end{array}$ & \\
\hline (Female Board)*(Female CFOs $)$ & $\begin{array}{l}59.55 \\
{[0.83]}\end{array}$ & & $\begin{array}{l}26.56 \\
{[0.10]}\end{array}$ & \\
\hline$\%$ Female Remu. & & $\begin{array}{c}195.51 * \\
{[1.87]}\end{array}$ & & $\begin{array}{c}1,045.58^{* *} \\
{[2.17]}\end{array}$ \\
\hline$(\text { Female Remu. })^{*}($ Female CFOs $)$ & & $\begin{array}{l}98.70 \\
{[1.31]}\end{array}$ & & $\begin{array}{c}251.43 \\
{[0.88]}\end{array}$ \\
\hline Board Size & $\begin{array}{c}37.70^{* * *} \\
{[4.90]}\end{array}$ & $\begin{array}{c}36.69 * * * \\
{[4.57]}\end{array}$ & $\begin{array}{c}204.42^{* * *} \\
{[4.07]}\end{array}$ & $\begin{array}{c}202.81^{* * *} \\
{[3.88]}\end{array}$ \\
\hline Insider Ratio & $\begin{array}{c}-162.19 \\
{[-1.46]}\end{array}$ & $\begin{array}{c}-158.57 \\
{[-1.61]}\end{array}$ & $\begin{array}{l}-31.38 \\
{[-0.08]}\end{array}$ & $\begin{array}{l}25.01 \\
{[0.06]}\end{array}$ \\
\hline Sales (ln) & $\begin{array}{c}66.17 * * * \\
{[10.39]}\end{array}$ & $\begin{array}{c}69.72^{* * *} \\
{[9.98]}\end{array}$ & $\begin{array}{c}224.32^{* * *} \\
{[5.77]}\end{array}$ & $\begin{array}{c}233.54^{* * *} \\
{[5.46]}\end{array}$ \\
\hline Leverage & $\begin{array}{c}7.21 \\
{[0.14]}\end{array}$ & $\begin{array}{l}-18.24 \\
{[-0.31]}\end{array}$ & $\begin{array}{l}70.28 \\
{[0.26]}\end{array}$ & $\begin{array}{l}40.10 \\
{[0.13]}\end{array}$ \\
\hline M/B Ratio & $\begin{array}{c}1.41 \\
{[0.44]}\end{array}$ & $\begin{array}{c}1.18 \\
{[0.35]}\end{array}$ & $\begin{array}{c}9.16 \\
{[0.76]}\end{array}$ & $\begin{array}{c}8.00 \\
{[0.61]}\end{array}$ \\
\hline ROA & $\begin{array}{l}-27.79 \\
{[-0.42]}\end{array}$ & $\begin{array}{l}-39.50 \\
{[-0.54]}\end{array}$ & $\begin{array}{c}-259.52 \\
{[-1.01]}\end{array}$ & $\begin{array}{c}-318.45 \\
{[-1.16]}\end{array}$ \\
\hline Stock Returns & $\begin{array}{l}-18.61 \\
{[-1.15]}\end{array}$ & $\begin{array}{l}-18.57 \\
{[-1.10]}\end{array}$ & $\begin{array}{c}132.35 \\
{[1.59]}\end{array}$ & $\begin{array}{c}136.52 \\
{[1.54]}\end{array}$ \\
\hline $\begin{array}{l}\text { Include fixed effects? (Industry \& Year) } \\
\text { Adjusted } R^{2} \\
\text { Total observations }\end{array}$ & $\begin{array}{l}\text { Yes } \\
56.30 \% \\
556\end{array}$ & $\begin{array}{l}\text { Yes } \\
56.15 \% \\
556\end{array}$ & $\begin{array}{l}\text { Yes } \\
57.29 \% \\
556\end{array}$ & $\begin{array}{l}\text { Yes } \\
57.26 \% \\
556\end{array}$ \\
\hline
\end{tabular}

This table presents the regression results on CFO compensation which is expressed in dollar value (\$'000), separately for Bonus, Salary, Total non-cash Comp. and Total Comp. The sample of 556 observations is for the years 2006 to 2010. Female CFOs is an indicator variable equal to 1 if the CFO is female. \% Female Board (or \% Female Remu.) is the proportion of female directors on the board (or on the remuneration committee). (Female Board)*(Female CFOs) (or (Female Remu.)*(Female CFOs )) is the interaction variable between the variable indicating the presence of female on the board (or on the remuneration committee) and the Female CFOs variable. MBA Qualification is a binary variable equal to 1 if the CFO has an MBA degree. CFO Board is a binary variable coded as one if the CFO is on the company board of directors. CFO Ownership is the percentage of company shares owned by the CFO. CFO Tenure is the number of years since the CFO was appointed, expressed in natural logarithm. Board Size is the number of directors on the board of directors. Insider Ratio is the percentage of executive directors on the board. Sales is the gross sales figure after credit and returns in prior year, expressed in natural logarithm. Leverage is firm financial leverage, calculated as total debt divided by market value of equity. $M / B$ Ratio is market value of equity divided by the book value of equity. $R O A$ is return on assets, calculated as earnings before tax divided by total assets. Stock Returns is the unadjusted return on company's shares during the year, calculated as the current year share price divided by the previous year share price, expressed in natural logarithm. Each regression uses the clustered standard errors estimation (Rogers 1993). It also includes industry-specific and year-specific fixed effects to control for systematic differences in compensation across industries and over time. Figures in square brackets are $t$-statistics. Emboldened figures indicate statistical significance at $10 \%$ level or better. $*$, ** or $* * *$ indicate statistical significance at the $10 \%, 5 \%$ or $1 \%$ level respectively. 
Table 5: Regression results on CFO compensation ( $\log ($ compensation)).

Panel A: Bonus and Non-cash compensation (log) - OLS regression

\begin{tabular}{|c|c|c|c|c|}
\hline & Ln(Bonus) & Ln(Bonus) & Ln(Non-cash) & Ln(Non-cash) \\
\hline Female CFOs & $\begin{array}{l}-0.46^{*} \\
{[-1.67]}\end{array}$ & $\begin{array}{l}-0.47^{*} \\
{[-1.66]}\end{array}$ & $\begin{array}{l}-0.55^{*} \\
{[-1.78]}\end{array}$ & $\begin{array}{l}-0.43^{*} \\
{[-1.66]}\end{array}$ \\
\hline MBA Qualification & $\begin{array}{c}0.26^{* * *} \\
{[2.68]}\end{array}$ & $\begin{array}{l}0.29^{*} \\
{[1.82]}\end{array}$ & $\begin{array}{c}0.22 \\
{[1.15]}\end{array}$ & $\begin{array}{c}0.24 \\
{[1.28]}\end{array}$ \\
\hline CFO Board & $\begin{array}{c}0.01 \\
{[0.03]}\end{array}$ & $\begin{array}{c}0.01 \\
{[0.08]}\end{array}$ & $\begin{array}{l}-0.03 \\
{[-0.15]}\end{array}$ & $\begin{array}{l}-0.02 \\
{[-0.12]}\end{array}$ \\
\hline CFO Ownership & $\begin{array}{c}0.15 \\
{[1.27]}\end{array}$ & $\begin{array}{c}0.08 \\
{[0.29]}\end{array}$ & $\begin{array}{c}0.55^{* * *} \\
{[2.61]}\end{array}$ & $\begin{array}{c}0.65 * * * \\
{[3.15]}\end{array}$ \\
\hline CFO Tenure (ln) & $\begin{array}{c}0.02 \\
{[0.18]}\end{array}$ & $\begin{array}{c}0.02 \\
{[0.22]}\end{array}$ & $\begin{array}{c}0.01 \\
{[0.11]}\end{array}$ & $\begin{array}{c}0.02 \\
{[0.15]}\end{array}$ \\
\hline$\%$ Female Board & $\begin{array}{c}0.18 \\
{[0.24]}\end{array}$ & & $\begin{array}{c}0.57 \\
{[0.70]}\end{array}$ & \\
\hline (Female Board $) *($ Female CFOs $)$ & $\begin{array}{c}0.15 \\
{[0.31]}\end{array}$ & & $\begin{array}{c}-0.87 \\
{[-0.90]}\end{array}$ & \\
\hline \% Female Remu. & & $\begin{array}{c}0.29 \\
{[0.71]}\end{array}$ & & $\begin{array}{l}1.08^{*} \\
{[1.92]}\end{array}$ \\
\hline (Female Remu.)*(Female CFOs) & & $\begin{array}{c}0.22 \\
{[0.41]}\end{array}$ & & $\begin{array}{c}-0.61 \\
{[-0.98]}\end{array}$ \\
\hline Board Size & $\begin{array}{c}0.12^{* * *} \\
{[3.41]}\end{array}$ & $\begin{array}{c}0.12 * * * \\
{[3.25]}\end{array}$ & $\begin{array}{c}0.14^{* * *} \\
{[3.05]}\end{array}$ & $\begin{array}{c}0.14^{* * *} \\
{[2.90]}\end{array}$ \\
\hline Insider ratio & $\begin{array}{c}0.14 \\
{[0.24]}\end{array}$ & $\begin{array}{c}0.23 \\
{[0.38]}\end{array}$ & $\begin{array}{l}-0.39 \\
{[-0.47]}\end{array}$ & $\begin{array}{c}-0.34 \\
{[-0.40]}\end{array}$ \\
\hline Sales (ln) & $\begin{array}{c}0.30^{* * *} \\
{[9.23]}\end{array}$ & $\begin{array}{c}0.31^{* * *} \\
{[8.87]}\end{array}$ & $\begin{array}{c}0.29^{* * *} \\
{[6.48]}\end{array}$ & $\begin{array}{c}0.28^{* * *} \\
{[6.09]}\end{array}$ \\
\hline Leverage & $\begin{array}{c}0.18 \\
{[0.56]}\end{array}$ & $\begin{array}{c}0.16 \\
{[0.50]}\end{array}$ & $\begin{array}{l}-0.03 \\
{[-0.07]}\end{array}$ & $\begin{array}{c}-0.04 \\
{[-0.08]}\end{array}$ \\
\hline M/B Ratio & $\begin{array}{l}-0.002 \\
{[-0.11]}\end{array}$ & $\begin{array}{l}-0.001 \\
{[-0.06]}\end{array}$ & $\begin{array}{l}0.03^{*} \\
{[1.68]}\end{array}$ & $\begin{array}{c}0.03 \\
{[1.33]}\end{array}$ \\
\hline ROA & $\begin{array}{l}-0.39 \\
{[-0.99]}\end{array}$ & $\begin{array}{l}-0.50 \\
{[-1.17]}\end{array}$ & $\begin{array}{l}-1.27 \\
{[-1.47]}\end{array}$ & $\begin{array}{l}-1.67 \\
{[-1.35]}\end{array}$ \\
\hline Stock Returns & $\begin{array}{l}0.21^{*} \\
{[1.73]}\end{array}$ & $\begin{array}{l}0.21^{*} \\
{[1.67]}\end{array}$ & $\begin{array}{c}-0.17 \\
{[-0.23]}\end{array}$ & $\begin{array}{l}-0.14 \\
{[-1.05]}\end{array}$ \\
\hline $\begin{array}{l}\text { Include fixed effects? (Industry \& Year) } \\
\text { Adjusted } R^{2} \\
\text { Total observations }\end{array}$ & $\begin{array}{l}\text { Yes } \\
53.07 \% \\
412\end{array}$ & $\begin{array}{l}\text { Yes } \\
52.64 \% \\
412\end{array}$ & $\begin{array}{l}\text { Yes } \\
32.52 \% \\
428\end{array}$ & $\begin{array}{c}\text { Yes } \\
33.09 \% \\
428\end{array}$ \\
\hline
\end{tabular}

continued on next page 
continued from previous page

Panel B: Salary and Total compensation (log) - OLS regression

\begin{tabular}{|c|c|c|c|c|}
\hline & Ln(Salary) & Ln(Salary) & Ln(Total comp.) & Ln(Total comp.) \\
\hline \multirow[t]{2}{*}{ Female CFOs } & $-0.19 *$ & $-0.23 * *$ & -0.19 & $-0.32^{* *}$ \\
\hline & {$[-1.88]$} & {$[-2.33]$} & {$[-1.52]$} & {$[-1.99]$} \\
\hline \multirow[t]{2}{*}{ MBA Qualification } & 0.08 & 0.05 & $0.13^{*}$ & 0.14 \\
\hline & [1.09] & {$[0.68]$} & {$[1.68]$} & {$[1.51]$} \\
\hline \multirow[t]{2}{*}{ CFO Board } & 0.08 & $0.10^{*}$ & 0.10 & 0.09 \\
\hline & {$[0.99]$} & {$[1.67]$} & {$[1.07]$} & {$[0.97]$} \\
\hline \multirow[t]{2}{*}{ CFO Ownership } & 0.04 & $0.18^{* *}$ & $0.17^{* *}$ & $0.17^{*}$ \\
\hline & {$[0.69]$} & {$[2.01]$} & {$[1.97]$} & {$[1.92]$} \\
\hline \multirow[t]{2}{*}{ CFO Tenure (ln) } & -0.01 & -0.03 & -0.01 & -0.01 \\
\hline & {$[-0.24]$} & {$[-0.88]$} & {$[-0.18]$} & {$[-0.15]$} \\
\hline \multirow[t]{2}{*}{$\%$ Female Board } & $0.53^{*}$ & & $0.93^{* *}$ & \\
\hline & {$[1.66]$} & & {$[2.12]$} & \\
\hline \multirow[t]{2}{*}{ (Female Board)*(Female CFOs $)$} & 0.26 & & -0.03 & \\
\hline & {$[1.01]$} & & {$[-0.12]$} & \\
\hline \multirow[t]{2}{*}{ \% Female Remu. } & & 0.24 & & $0.65 * *$ \\
\hline & & {$[1.22]$} & & {$[2.39]$} \\
\hline \multirow[t]{2}{*}{$($ Female Remu.)*(Female CFOs) } & & 0.29 & & 0.29 \\
\hline & & {$[1.54]$} & & {$[1.11]$} \\
\hline \multirow[t]{2}{*}{ Board Size } & $0.05^{* * *}$ & $0.05^{* * *}$ & $0.09 * * *$ & $0.09 * * *$ \\
\hline & {$[2.96]$} & {$[2.73]$} & {$[4.07]$} & {$[3.95]$} \\
\hline \multirow[t]{2}{*}{ Insider ratio } & -0.36 & -0.42 & -0.50 & -0.46 \\
\hline & {$[-1.63]$} & {$[-1.57]$} & {$[-1.60]$} & {$[-1.54]$} \\
\hline \multirow[t]{2}{*}{ Sales (ln) } & $0.15 * * *$ & $0.16^{* * *}$ & $0.21^{* * *}$ & $0.21 * * *$ \\
\hline & {$[10.47]$} & {$[10.19]$} & {$[9.78]$} & {$[10.06]$} \\
\hline \multirow[t]{2}{*}{ Leverage } & 0.10 & 0.07 & 0.07 & 0.06 \\
\hline & {$[0.71]$} & {$[0.47]$} & {$[0.37]$} & {$[0.29]$} \\
\hline \multirow[t]{2}{*}{ M/B Ratio } & -0.001 & -0.001 & 0.003 & 0.001 \\
\hline & {$[-0.10]$} & {$[-0.07]$} & {$[0.24]$} & {$[0.08]$} \\
\hline \multirow[t]{2}{*}{ ROA } & -0.05 & -0.08 & -0.23 & -0.26 \\
\hline & {$[-0.32]$} & {$[-0.47]$} & {$[-1.02]$} & {$[-1.12]$} \\
\hline \multirow[t]{2}{*}{ Stock Returns } & -0.13 & -0.11 & 0.05 & 0.05 \\
\hline & {$[-1.44]$} & {$[-1.18]$} & {$[0.74]$} & {$[0.81]$} \\
\hline Include fixed effects? (Industry \& Year) & Yes & Yes & Yes & Yes \\
\hline Adjusted $R^{2}$ & $59.83 \%$ & $59.45 \%$ & $58.15 \%$ & $58.61 \%$ \\
\hline Total observations & 556 & 556 & 556 & 556 \\
\hline
\end{tabular}

This table presents the regression results on CFO compensation which is expressed in natural logarithm, separately for Bonus, Salary, Total non-cash Comp. and Total Comp. The sample of 556 observations is for the years 2006 to 2010. Female CFOs is an indicator variable equal to 1 if the CFO is female. \% Female Board (or \% Female Remu.) is the proportion of female directors on the board (or on the remuneration committee). (Female Board)*(Female CFOs) (or (Female Remu.)*(Female CFOs)) is the interaction variable between the variable indicating the presence of female on the board (or on the remuneration committee) and the Female CFOs variable. MBA Qualification is a binary variable equal to 1 if the $\mathrm{CFO}$ has an MBA degree. CFO Board is a binary variable coded as one if the CFO is on the company board of directors. CFO Ownership is the percentage of company shares owned by the CFO. CFO Tenure is the number of years since the CFO was appointed, expressed in natural logarithm. Board Size is the number of directors on the board of directors. Insider Ratio is the percentage of executive directors on the board. Sales is the gross sales figure after credit and returns in prior year, expressed in natural logarithm. Leverage is firm financial leverage, calculated as total debt divided by market value of equity. $M / B$ Ratio is market value of equity divided by the book value of equity. ROA is return on assets, calculated as earnings before tax divided by total assets. Stock Returns is the unadjusted return on company's shares during the year, calculated as the current year share price divided by the previous year share price, expressed in natural logarithm. Each regression uses the clustered standard errors estimation (Rogers 1993). It also includes industry-specific and year-specific fixed effects to control for systematic differences in compensation across industries and over time. Figures in square brackets are $t$-statistics. Emboldened figures indicate statistical significance at $10 \%$ level or better. $*, * *$, or $* * *$ indicate statistical significance at the $10 \%, 5 \%$ or $1 \%$ level respectively. 
Table 6: Regression results on CFO compensation structure.

Panel A: Proportion of Bonus/ Non-cash compensation to Total compensation (\%) - Tobit regression

\begin{tabular}{|c|c|c|c|c|}
\hline & Prop. Bonus & Prop. Bonus & Prop. Non-cash & Prop. Non-cash \\
\hline Female CFOs & $\begin{array}{c}-5.85^{* *} \\
{[-2.06]}\end{array}$ & $\begin{array}{c}-4.66^{* *} \\
{[-1.98]}\end{array}$ & $\begin{array}{l}-2.18^{*} \\
{[-1.65]}\end{array}$ & $\begin{array}{l}-2.39^{*} \\
{[-1.68]}\end{array}$ \\
\hline MBA Qualification & $\begin{array}{c}4.93^{* * *} \\
{[2.68]}\end{array}$ & $\begin{array}{c}5.07^{* * *} \\
{[2.71]}\end{array}$ & $\begin{array}{c}3.24 \\
{[1.57]}\end{array}$ & $\begin{array}{l}3.42^{*} \\
{[1.65]}\end{array}$ \\
\hline CFO Board & $\begin{array}{l}-1.52 \\
{[-0.87]}\end{array}$ & $\begin{array}{c}-0.53 \\
{[-0.31]}\end{array}$ & $\begin{array}{l}-1.71 \\
{[-0.88]}\end{array}$ & $\begin{array}{l}-1.51 \\
{[-0.77]}\end{array}$ \\
\hline CFO Ownership & $\begin{array}{l}-0.24 \\
{[-0.10]}\end{array}$ & $\begin{array}{l}-2.58 \\
{[-1.09]}\end{array}$ & $\begin{array}{c}0.62 \\
{[0.38]}\end{array}$ & $\begin{array}{c}2.84 \\
{[1.13]}\end{array}$ \\
\hline CFO Tenure (ln) & $\begin{array}{c}-0.51 \\
{[-0.47]}\end{array}$ & $\begin{array}{l}-0.20 \\
{[-0.18]}\end{array}$ & $\begin{array}{l}-1.75 \\
{[-1.43]}\end{array}$ & $\begin{array}{l}-1.52 \\
{[-1.27]}\end{array}$ \\
\hline$\%$ Female Board & $\begin{array}{c}1.87 \\
{[0.21]}\end{array}$ & & $\begin{array}{c}25.12^{* * *} \\
{[2.67]}\end{array}$ & \\
\hline (Female Board $) *($ Female CFOs $)$ & $\begin{array}{c}-0.03 \\
{[-0.01]}\end{array}$ & & $\begin{array}{l}-5.40 \\
{[-0.92]}\end{array}$ & \\
\hline$\%$ Female Remu. & & $\begin{array}{c}2.59 \\
{[0.49]}\end{array}$ & & $\begin{array}{c}23.51^{* * *} \\
{[4.18]}\end{array}$ \\
\hline$($ Female Remu.)*(Female CFOs) & & $\begin{array}{l}-1.32 \\
{[-0.21]}\end{array}$ & & $\begin{array}{l}-12.01 \\
{[-1.61]}\end{array}$ \\
\hline Board Size & $\begin{array}{c}0.12 \\
{[0.29]}\end{array}$ & $\begin{array}{c}28.46^{* * *} \\
{[2.60]}\end{array}$ & $\begin{array}{c}1.16^{* *} \\
{[2.29]}\end{array}$ & $\begin{array}{c}1.07^{* *} \\
{[2.09]}\end{array}$ \\
\hline Insider Ratio & $\begin{array}{l}-4.81 \\
{[-0.74]}\end{array}$ & $\begin{array}{l}-39.36 \\
{[-0.22]}\end{array}$ & $\begin{array}{c}-9.91 \\
{[-1.46]}\end{array}$ & $\begin{array}{l}-9.94 \\
{[-1.41]}\end{array}$ \\
\hline Sales $(\ln )$ & $\begin{array}{c}2.60^{* * *} \\
{[6.23]}\end{array}$ & $\begin{array}{c}2.28^{* * *} \\
{[6.28]}\end{array}$ & $\begin{array}{c}1.62^{* * *} \\
{[3.75]}\end{array}$ & $\begin{array}{c}1.36^{* * *} \\
{[2.99]}\end{array}$ \\
\hline Leverage & $\begin{array}{l}-1.11 \\
{[-0.25]}\end{array}$ & $\begin{array}{c}1.24 \\
{[0.31]}\end{array}$ & $\begin{array}{c}0.62 \\
{[0.10]}\end{array}$ & $\begin{array}{c}3.05 \\
{[0.47]}\end{array}$ \\
\hline M/B Ratio & $\begin{array}{c}0.01 \\
{[0.06]}\end{array}$ & $\begin{array}{c}0.06 \\
{[0.34]}\end{array}$ & $\begin{array}{l}0.44^{* *} \\
{[2.29]}\end{array}$ & $\begin{array}{l}0.40^{* *} \\
{[1.98]}\end{array}$ \\
\hline ROA & $\begin{array}{c}3.22 \\
{[0.76]}\end{array}$ & $\begin{array}{c}3.37 \\
{[0.85]}\end{array}$ & $\begin{array}{l}-6.82 \\
{[-1.31]}\end{array}$ & $\begin{array}{l}-69.58 \\
{[-0.45]}\end{array}$ \\
\hline Stock Returns & $\begin{array}{c}\text { 6.09*** } \\
{[3.72]}\end{array}$ & $\begin{array}{c}\text { 6.03*** } \\
{[3.63]}\end{array}$ & $\begin{array}{c}1.39 \\
{[0.84]}\end{array}$ & $\begin{array}{c}1.46 \\
{[0.85]}\end{array}$ \\
\hline $\begin{array}{l}\text { Include fixed effects? } \\
\text { (Industry \& Year) }\end{array}$ & Yes & Yes & Yes & Yes \\
\hline No. zero observations & 144 & 144 & 128 & 128 \\
\hline No. non-zero obs. & 412 & 412 & 428 & 428 \\
\hline Total observations & 556 & 556 & 556 & 556 \\
\hline
\end{tabular}

continued on next page 
continued from previous page

Panel B: Proportion of Salary/ Cash compensation to Total compensation (\%) - OLS regression

\begin{tabular}{|c|c|c|c|c|}
\hline & Prop. Salary & Prop. Salary & Prop. Cash & Prop. Cash \\
\hline Female CFOs & $\begin{array}{c}6.28^{* *} \\
{[2.13]}\end{array}$ & $\begin{array}{l}3.27^{*} \\
{[1.89]}\end{array}$ & $\begin{array}{l}2.32^{*} \\
{[1.65]}\end{array}$ & $\begin{array}{l}2.11^{*} \\
{[1.67]}\end{array}$ \\
\hline MBA Qualification & $\begin{array}{c}-1.03 \\
{[-0.34]}\end{array}$ & $\begin{array}{l}-1.78 \\
{[-0.57]}\end{array}$ & $\begin{array}{c}0.26 \\
{[0.07]}\end{array}$ & $\begin{array}{c}0.27 \\
{[0.07]}\end{array}$ \\
\hline CFO Board & $\begin{array}{c}1.35 \\
{[0.68]}\end{array}$ & $\begin{array}{c}1.04 \\
{[0.53]}\end{array}$ & $\begin{array}{c}2.48 \\
{[1.16]}\end{array}$ & $\begin{array}{c}2.04 \\
{[0.96]}\end{array}$ \\
\hline CFO Ownership & $\begin{array}{c}-0.70 \\
{[-0.32]}\end{array}$ & $\begin{array}{c}-0.72 \\
{[-0.22]}\end{array}$ & $\begin{array}{c}-1.57 \\
{[-0.95]}\end{array}$ & $\begin{array}{c}-3.62 \\
{[-1.23]}\end{array}$ \\
\hline CFO Tenure (ln) & $\begin{array}{c}1.67 \\
{[1.10]}\end{array}$ & $\begin{array}{c}0.47 \\
{[0.35]}\end{array}$ & $\begin{array}{l}2.92^{*} \\
{[1.67]}\end{array}$ & $\begin{array}{l}2.49^{*} \\
{[1.69]}\end{array}$ \\
\hline$\%$ Female Board & $\begin{array}{c}3.66 \\
{[1.19]}\end{array}$ & & $\begin{array}{c}1.05 \\
{[0.28]}\end{array}$ & \\
\hline$($ Female Board $) *($ Female CFOs $)$ & $\begin{array}{c}-5.08 \\
{[-0.76]}\end{array}$ & & $\begin{array}{c}-2.31 \\
{[-0.36]}\end{array}$ & \\
\hline$\%$ Female Remu. & & $\begin{array}{l}-19.94 \\
{[-1.63]}\end{array}$ & & $\begin{array}{l}-23.32 \\
{[-1.39]}\end{array}$ \\
\hline$(\text { Female Remu. })^{*}($ Female CFOs $)$ & & $\begin{array}{c}1.67 \\
{[0.30]}\end{array}$ & & $\begin{array}{l}12.76 \\
{[1.41]}\end{array}$ \\
\hline Board Size & $\begin{array}{c}-1.06 \\
{[-1.16]}\end{array}$ & $\begin{array}{c}36.69 * * * \\
{[4.57]}\end{array}$ & $\begin{array}{c}-0.04 \\
{[-0.03]}\end{array}$ & $\begin{array}{c}0.13 \\
{[0.10]}\end{array}$ \\
\hline Insider Ratio & $\begin{array}{c}14.82^{* *} \\
{[1.97]}\end{array}$ & $\begin{array}{c}-158.57 \\
{[-1.61]}\end{array}$ & $\begin{array}{c}14.06^{*} \\
{[1.75]}\end{array}$ & $\begin{array}{l}12.22 \\
{[1.62]}\end{array}$ \\
\hline Sales (ln) & $\begin{array}{c}-3.40^{* * *} \\
{[-5.80]}\end{array}$ & $\begin{array}{c}-2.82^{* * *} \\
{[-4.74]}\end{array}$ & $\begin{array}{c}-1.77^{* * *} \\
{[-2.81]}\end{array}$ & $\begin{array}{c}-1.42^{* *} \\
{[-2.04]}\end{array}$ \\
\hline Leverage & $\begin{array}{c}7.61 \\
{[1.04]}\end{array}$ & $\begin{array}{c}5.18 \\
{[0.67]}\end{array}$ & $\begin{array}{c}8.58 \\
{[0.99]}\end{array}$ & $\begin{array}{c}8.46 \\
{[0.86]}\end{array}$ \\
\hline M/B Ratio & $\begin{array}{c}-0.20 \\
{[-0.92]}\end{array}$ & $\begin{array}{c}-0.19 \\
{[-0.76]}\end{array}$ & $\begin{array}{c}-0.39 * * \\
{[-1.99]}\end{array}$ & $\begin{array}{c}-0.35 \\
{[-1.56]}\end{array}$ \\
\hline $\mathrm{ROA}$ & $\begin{array}{c}12.16^{* * *} \\
{[2.67]}\end{array}$ & $\begin{array}{c}16.24^{* * *} \\
{[2.59]}\end{array}$ & $\begin{array}{c}15.56^{* * *} \\
{[2.87]}\end{array}$ & $\begin{array}{c}19.06^{* * *} \\
{[2.86]}\end{array}$ \\
\hline Stock Returns & $\begin{array}{c}-9.81 \\
{[-1.56]}\end{array}$ & $\begin{array}{c}-9.68 \\
{[-1.37]}\end{array}$ & $\begin{array}{l}-5.39 \\
{[-1.47]}\end{array}$ & $\begin{array}{l}-5.81 \\
{[-1.44]}\end{array}$ \\
\hline $\begin{array}{l}\text { Include fixed effects? (Industry \& Year) } \\
\text { Adjusted } R^{2} \\
\text { Total observations }\end{array}$ & $\begin{array}{l}\text { Yes } \\
18.14 \% \\
556\end{array}$ & $\begin{array}{l}\text { Yes } \\
18.03 \% \\
556\end{array}$ & $\begin{array}{l}\text { Yes } \\
9.29 \% \\
556\end{array}$ & $\begin{array}{l}\text { Yes } \\
9.08 \% \\
556\end{array}$ \\
\hline
\end{tabular}

This table presents the regression results on CFO compensation structure. The dependent variables are Prop. Bonus and Prop. Non-cash (in Panel A), Prop. Salary and Prop. Cash (in Panel B) which are calculated as the percentage of bonus, non-cash compensation, salary or cash compensation to total compensation, respectively. The sample of 556 observations is for the years 2006 to 2010. Female CFOs is an indicator variable equal to 1 if the CFO is female. \% Female Board (or \% Female Remu.) is the proportion of female directors on the board (or on the remuneration committee). (Female Board)*(Female CFOs) (or (Female Remu.)*(Female CFOs)) is the interaction variable between the variable indicating the presence of female on the board (or on the remuneration committee) and the Female $C F O s$ variable. $M B A$ Qualification is a binary variable equal to 1 if the CFO has an MBA degree. CFO Board is a binary variable coded as one if the CFO is on the company board of directors. CFO Ownership is the percentage of company shares owned by the CFO. CFO Tenure is the number of years since the CFO was appointed, expressed in natural logarithm. Board Size is the number of directors on the board of directors. Insider Ratio is the percentage of executive directors on the board. Sales is the gross sales figure after credit and returns in prior year, expressed in natural logarithm. Leverage is firm financial leverage, calculated as total debt divided by market value of equity. $M / B$ Ratio is market value of equity divided by the book value of equity. ROA is return on assets, calculated as earnings before tax divided by total assets. Stock Returns is the unadjusted return on company's shares during the year, calculated as the current year share price divided by the previous year share price, expressed in natural logarithm. Each regression uses the clustered standard errors estimation (Rogers 1993). It also includes industry-specific and year-specific fixed effects to control for systematic differences in compensation across industries and over time. Figures in square brackets are $t$-statistics. Emboldened figures indicate statistical significance at $10 \%$ level or better. $* * *$, or $* * *$ indicate statistical significance at the $10 \%, 5 \%$ or $1 \%$ level respectively. 
Table 7: Regression results on earnings management.

\begin{tabular}{|c|c|c|c|c|}
\hline & \multicolumn{2}{|c|}{$\mathrm{AM}$} & \multicolumn{2}{|c|}{ RTM } \\
\hline & $(1)$ & $(2)$ & $(3)$ & $(4)$ \\
\hline Female CFOs & $\begin{array}{l}-0.04^{*} \\
{[-1.72]}\end{array}$ & $\begin{array}{c}-0.05^{* *} \\
{[-1.97]}\end{array}$ & $\begin{array}{l}-0.08^{*} \\
{[-1.74]}\end{array}$ & $\begin{array}{c}-0.11^{* *} \\
{[-2.48]}\end{array}$ \\
\hline CFO Board & $\begin{array}{c}0.01 \\
{[0.61]}\end{array}$ & $\begin{array}{l}0.001 \\
{[0.12]}\end{array}$ & $\begin{array}{l}-0.05 \\
{[-1.01]}\end{array}$ & $\begin{array}{l}-0.05 \\
{[-0.98]}\end{array}$ \\
\hline CFO Ownership & $\begin{array}{c}0.03 \\
{[1.03]}\end{array}$ & $\begin{array}{c}0.05 \\
{[1.34]}\end{array}$ & $\begin{array}{c}0.11^{* * *} \\
{[3.25]}\end{array}$ & $\begin{array}{c}0.11^{* *} \\
{[2.50]}\end{array}$ \\
\hline CFO Tenure (ln) & $\begin{array}{l}0.003 \\
{[0.44]}\end{array}$ & $\begin{array}{l}0.003 \\
{[0.45]}\end{array}$ & $\begin{array}{l}-0.01 \\
{[-0.47]}\end{array}$ & $\begin{array}{l}-0.003 \\
{[-0.14]}\end{array}$ \\
\hline Female Dir. Board & $\begin{array}{l}-0.02 * \\
{[-1.90]}\end{array}$ & & $\begin{array}{c}-0.03 \\
{[-0.88]}\end{array}$ & \\
\hline Female Dir. Remu. & & $\begin{array}{c}-0.01 \\
{[-0.71]}\end{array}$ & & $\begin{array}{l}-0.03 \\
{[-0.98]}\end{array}$ \\
\hline AC Size & $\begin{array}{l}0.002 \\
{[0.36]}\end{array}$ & $\begin{array}{l}0.002 \\
{[0.36]}\end{array}$ & $\begin{array}{l}0.001 \\
{[0.07]}\end{array}$ & $\begin{array}{l}-0.001 \\
{[-0.06]}\end{array}$ \\
\hline PAFE & $\begin{array}{l}-0.002 \\
{[-0.08]}\end{array}$ & $\begin{array}{l}0.002 \\
{[0.06]}\end{array}$ & $\begin{array}{l}-0.03 \\
{[-0.61]}\end{array}$ & $\begin{array}{c}-0.04 \\
{[-0.81]}\end{array}$ \\
\hline Total Assets (ln) & $\begin{array}{c}-0.01 * * \\
{[-2.34]}\end{array}$ & $\begin{array}{c}-0.01 * * * \\
{[-2.93]}\end{array}$ & $\begin{array}{l}-0.02 \\
{[-1.17]}\end{array}$ & $\begin{array}{l}-0.02 \\
{[-1.44]}\end{array}$ \\
\hline Leverage & $\begin{array}{l}-0.01 \\
{[-0.21]}\end{array}$ & $\begin{array}{l}-0.002 \\
{[-0.08]}\end{array}$ & $\begin{array}{c}0.05 \\
{[0.67]}\end{array}$ & $\begin{array}{l}-0.003 \\
{[-0.01]}\end{array}$ \\
\hline M/B Ratio & $\begin{array}{l}0.001 \\
{[1.02]}\end{array}$ & $\begin{array}{l}0.001 \\
{[1.53]}\end{array}$ & $\begin{array}{c}0.03 \\
{[1.23]}\end{array}$ & $\begin{array}{c}0.03 \\
{[1.22]}\end{array}$ \\
\hline Prop. Loss Years & $\begin{array}{c}0.01 \\
{[0.49]}\end{array}$ & $\begin{array}{l}0.002 \\
{[0.10]}\end{array}$ & $\begin{array}{c}0.08 \\
{[1.14]}\end{array}$ & $\begin{array}{c}0.08 \\
{[1.13]}\end{array}$ \\
\hline Std dev (Sales/TA) & $\begin{array}{l}-0.004 \\
{[-0.46]}\end{array}$ & $\begin{array}{c}-0.01 \\
{[-0.99]}\end{array}$ & $\begin{array}{l}-0.03 \\
{[-1.15]}\end{array}$ & $\begin{array}{c}-0.03 * * \\
{[-2.21]}\end{array}$ \\
\hline Std dev $(\mathrm{CF} / \mathrm{TA})$ & $\begin{array}{l}0.004 \\
{[0.18]}\end{array}$ & $\begin{array}{l}-0.02 \\
{[-1.63]}\end{array}$ & $\begin{array}{c}0.07 \\
{[1.32]}\end{array}$ & $\begin{array}{c}0.07 \\
{[1.33]}\end{array}$ \\
\hline $\begin{array}{l}\text { Include fixed effects? (Industry \& Year) } \\
\text { Adjusted } R^{2} \\
\text { Total observations }\end{array}$ & $\begin{array}{l}\text { Yes } \\
9.93 \% \\
437\end{array}$ & $\begin{array}{c}\text { Yes } \\
10.53 \% \\
437\end{array}$ & $\begin{array}{c}\text { Yes } \\
18.91 \% \\
437\end{array}$ & $\begin{array}{c}\text { Yes } \\
15.68 \% \\
437\end{array}$ \\
\hline
\end{tabular}

This table presents the regression results on earnings management. $A M$ is the proxy of accruals management, accrual estimation errors. RTM is the proxy for real transactions manipulation. Female CFOs is an indicator variable equal to 1 if the $\mathrm{CFO}$ is female. CFO Board is a binary variable coded as one if the CFO is on the company board of directors. $C F O$ Ownership is the percentage of company shares owned by the CFO. CFO Tenure is the number of years since the CFO was appointed, expressed in natural logarithm. Female Dir. Board is a dummy variable equal to 1 if there is a presence of female directors on the board. Female Dir. Remu is a binary variable equal to 1 if there is a presence of female directors on the remuneration committee. AC Size is the size of audit committee. PAFE is the proportion of directors on the audit committee who have financial accounting expertise. Total Assets is the company total assets in prior year, expressed in natural logarithm. Leverage is firm financial leverage, calculated as total debt divided by market value of equity. $M / B$ Ratio is market value of equity divided by the book value of equity. Prop. Loss Years is the proportion of years that a company made loss over the last 6 years. Std dev (Sales/TA) (or Std $\operatorname{dev}(C F / T A)$ ) is the standard deviation of sales (or operating cash flows) scaled by total assets over the previous 5 years. Each regression uses the clustered standard errors estimation (Rogers 1993). It also includes industry-specific and year-specific fixed effects to control for systematic differences in compensation across industries and over time. Figures in square brackets are $t$-statistics. Emboldened figures indicate statistical significance at $10 \%$ level or better. ${ }^{*},{ }^{*}$, or ${ }^{* *}$ indicate statistical significance at the $10 \%, 5 \%$ or $1 \%$ level respectively. 